\title{
WATER QUALITY OF STREAMS AND SPRINGS, GREEN RIVER BASIN, WYOMING
}

By

Lewis L. DeLong

U.S. GEOLOGICAL SURVEY

Water-Resources Investigations Report 82-4008

Prepared in cooperation with the

U.S. Bureau of Land Management

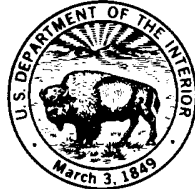

Cheyenne, Wyoming 1986 


\title{
UNITED STATES DEPARTMENT OF THE INTERIOR
}

\author{
DONALD PAUL HODEL, SECRETARY
}

\section{GEOLOGICAL SURVEY}

Dallas L. Peck, Director

For additional information write to:

\section{District Chief}

U.S. Geological Survey

P.O. Box 1125

Cheyenne, Wyoming
Copies of this report can be purchased from:

Open-File Services Section

Western Distribution Branch

U.S. Geological Survey

Box 25425, Federal Center

Denver, Colorado $\mathbf{8 0 2 2 5}$

(Telephone: (303) 236-7476) 


\section{CONTENTS}

Page

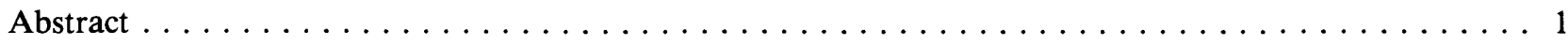

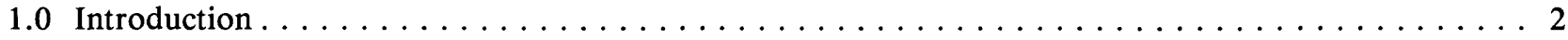

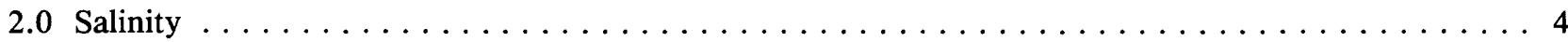

2.1 Dissolved-solids loads and average concentrations $\ldots \ldots \ldots \ldots \ldots \ldots \ldots \ldots \ldots \ldots \ldots$

2.2 Estimating effects of water development $\ldots \ldots \ldots \ldots \ldots \ldots \ldots \ldots \ldots \ldots \ldots \ldots \ldots \ldots \ldots$

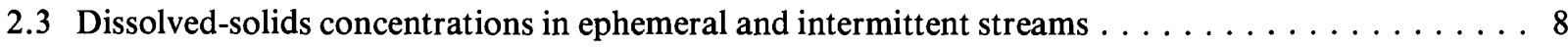

2.4 Relative calcium, sulfate and sodium concentrations $\ldots \ldots \ldots \ldots \ldots \ldots \ldots \ldots \ldots \ldots \ldots$

2.5 Chemical composition of water in samples from springs $\ldots \ldots \ldots \ldots \ldots \ldots \ldots \ldots \ldots \ldots$

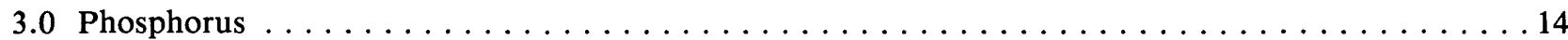

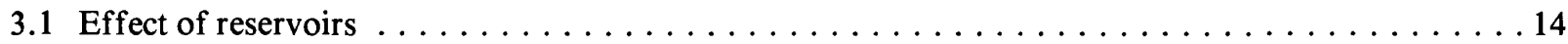

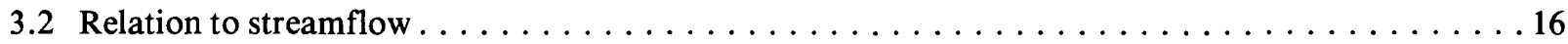

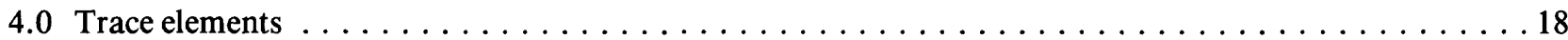

5.0 Estimation of means and standard deviations of distributions affected

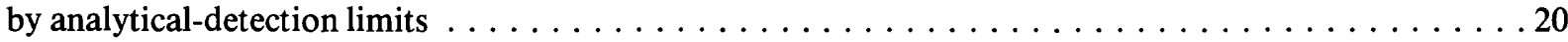

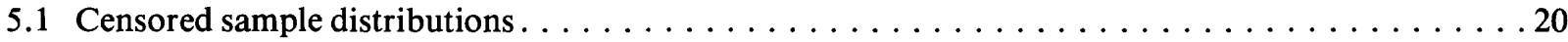

5.2 Geometric means. . . . . . . . . . . . 22

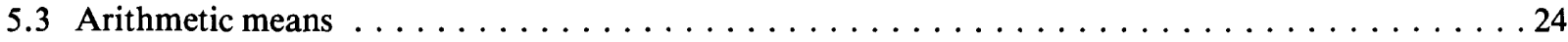

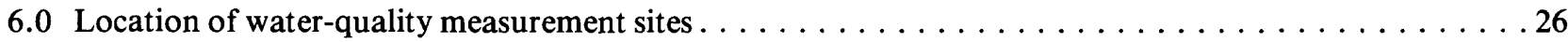

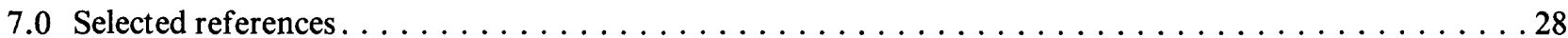

8.0 Statistical summary of trace-element concentrations at routine

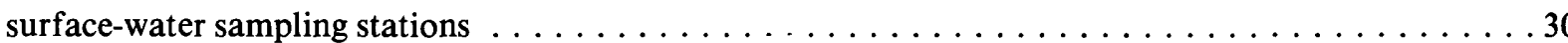

\section{CONVERSION FACTORS}

The following factors may be used to convert the inch-pound units used in this report to the International System of Units (SI):

Multiply

cubic foot per second

ton per day

mile
By

0.02832

0.9072

0.6214
To obtain

cubic meter per second

megagram per day

kilometer

\section{STATION NUMBERS}

Routine surface-water sampling stations are identified by 8-digit station numbers. The complete station number, such as 09188500 , includes the first two digits " 09 " that refer to the major drainage basin, and the remaining six digits " 188500 " that refer to individual station location. Progressively higher location numbers refer to locations progressively farther downstream. 


\title{
WATER QUALITY OF STREAMS AND SPRINGS, GREEN RIVER BASIN, WYOMING
}

By

Lewis L. DeLong

\begin{abstract}
Data on salinity, phosphorus, and trace elements in streams and springs within the Green River basin in Wyoming are summarized. Relative contributions of salinity are shown through estimates of annual loads and average concentrations at 11 water-quality measurement sites for the 1970-77 water years. A hypothetical diversion of 20 cubic feet per second from the Big Sandy River would decrease dissolvedsolids concentrations in the Green River at Green River, Wyoming. This effect would be greatest during the winter months, decreasing dissolved-solids concentrations as much as 13 percent. Decreases in dissolved-solids concentrations during the remainder of the year generally would be less than 2 percent.

Unlike the dilution effect that overland runoff has on perennial streams, runoff in ephemeral and intermittent streams within the basin was found to be enriched by the flushing of salts from normally dry channels and basin surfaces.

Relative concentrations of sodium and sulfate in streams within the basin appear to be controlled by availability, whereas calcium concentrations appear

of increasing relative concentrations of sodium, sulfate, or both with increasing dissolved-solids concentrations was evident in all streams sampled.

Estimates of total phosphorus concentrations at water-quality measurement sites indicate that phosphorus is removed from water of the Green River as it passes through Fontenelle and Flaming Gorge Reservoirs. Total phosphorus concentrations at some stream sites are either directly or inversely related to streamflow, but at most sites a simple relation is not discernable.

Trace-element concentrations in many of the water samples from streams and springs were less than analytical-detection limits. A ranking procedure was used to calculate cumulative probabilities of concentrations in distributions affected by analytical detection limits. Thus, the number of samples with concentrations less than detection limits and the number and concentrations of samples with concentrations greater than detection limits were used to provide more realistic estimates of means and standard deviations.
\end{abstract} to be controlled by solubility. A downstream trend 


\subsection{INTRODUCTION}

\section{This report summarizes water-quality data for streams and springs in the Green River basin in Wyoming.}

Demand for water in the Green River basin in Wyoming (fig. 1.0-1) is rapidly increasing due to development of extensive coal, oil, gas, and trona resources. The potential also exists for development of extensive oil-shale resources. The increasing demand for water and, consequently, an increasing demand for water-quality information has led to the initiation and expansion of data-collection programs by many State and Federal agencies. This report, a component of a complete basin study described by Lowham and others (1976), summarizes water-quality data and associated interpretations primarily for persons concerned with planning and managing water development and monitoring the resulting effects on surface-water quality. Data analyzed are from samples collected between October 1965 and June 1979. Data are available from computer storage (U.S. Geological Survey, 1974) and may be found in publications such as Water Resources Data for Wyoming (U.S. Geological Survey, 1976; 1977).

Salinity, phosphorus, and trace elements are described in separate sections followed by a section describing methods used in this report to summarize water-quality data affected by analytical-detection limits. 


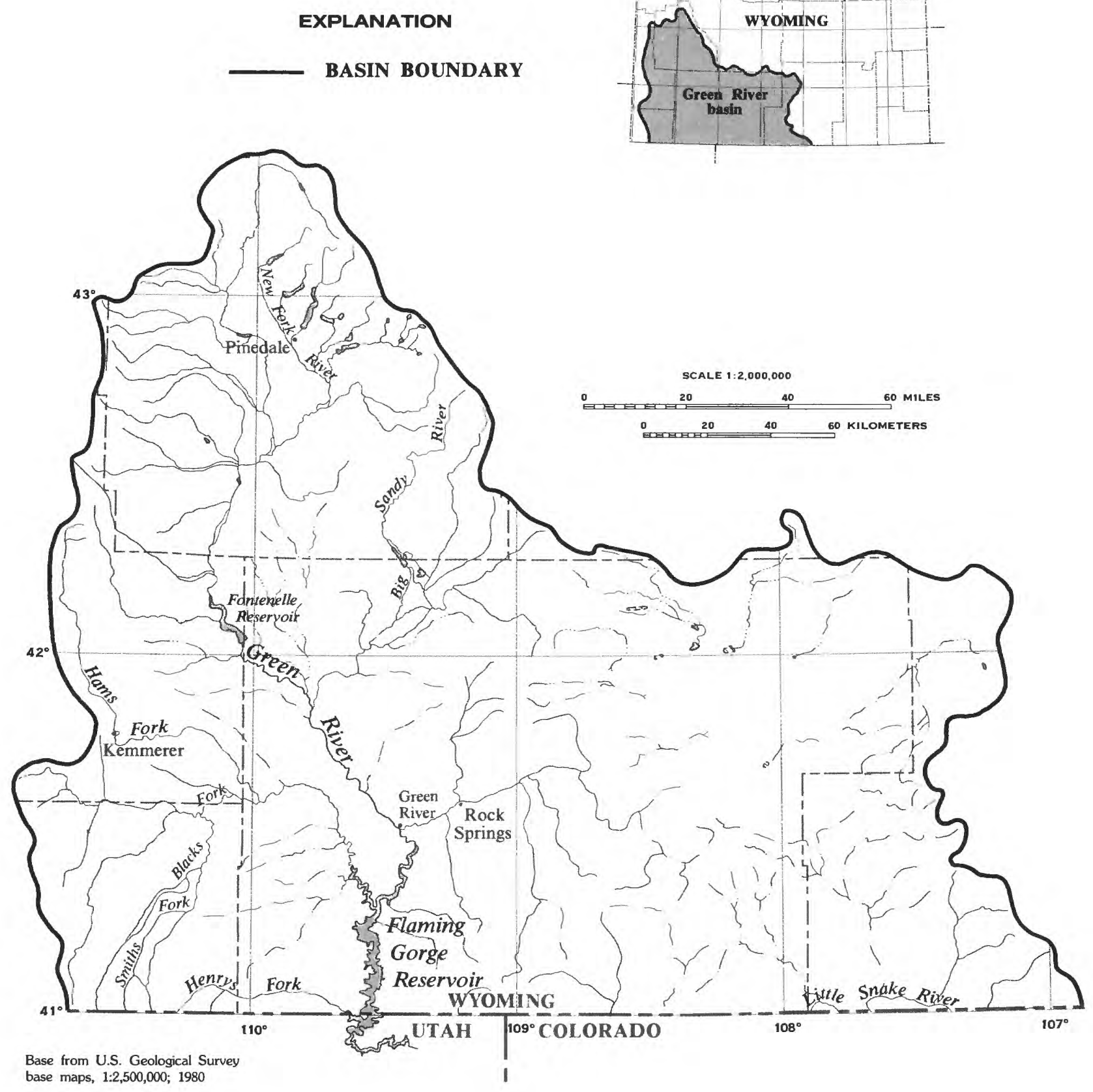

Figure 1.0-1 Location of the Green River basin in Wyoming. 


\subsection{SALINITY}

2.1 Dissolved-Solids Loads and Average Concentrations

\section{Relative contributions of salinity may be seen in loads estimated at water-quality measurement sites on the Green River and its major tributaries.}

Water quality, specifically salinity, is an important factor in determining water use and in assessing possible impacts of those uses with time. Development of extensive energy resources in the Green River basin and other parts of Wyoming could result in a significant increase in water consumption from the Green River (Wyoming Water Planning Program, 1970).

Quantitative description of salinity in the Green River and its major tributaries is useful in evaluating existing water quality as well as projecting impacts of proposed or existing surface-water developments. Dissolved-solids concentrations and loads in this report are estimated from periodic samples and streamflow records using a regression model that relates dissolved-solids concentrations to daily streamflow and time of the year (DeLong, 1977). Considerable variability in annual loads and average concentrations at individual stations is apparent (figs. 2.1-1 and 2.1-2). Generally smaller annual loads and larger average concentrations during the 1977 water year were a result of less than normal runoff (table 2.1-1). The average discharge during the 1977 water year at station 09217000 , Green River near Green River, Wyoming, was less than one-half the average discharge during the preceding 26 years (U.S. Geological Survey, 1977).

Table 2.1-1 Dissolved-solids loads and average concentrations, 1970-77 water years.

EXAMPLE: 74,020 Tons per year

166 Milligrams per liter

\begin{tabular}{|c|c|c|c|c|c|c|c|c|}
\hline Station & 1970 & 1971 & 1972 & 1973 & 1974 & 1975 & 1976 & 1977 \\
\hline \multirow[t]{2}{*}{09188500} & 74,020 & 95,080 & 102,400 & 81,230 & 94,260 & 74,910 & 88,120 & 55,870 \\
\hline & 166 & 140 & 155 & 183 & 158 & 146 & 165 & 213 \\
\hline \multirow[t]{2}{*}{09205000} & 52,890 & 68,730 & 79,230 & 67,670 & 68,900 & 66,120 & 65,990 & 39,660 \\
\hline & 97 & 80 & 74 & 94 & 86 & 84 & 85 & 129 \\
\hline \multirow[t]{2}{*}{09209400} & 227,200 & 378,500 & 442,400 & 291,800 & 335,400 & 294,500 & 342,900 & 144,600 \\
\hline & 188 & 169 & 175 & 199 & 192 & 166 & 184 & 220 \\
\hline \multirow[t]{2}{*}{09211200} & 299,500 & 443,000 & 543,100 & 347,500 & 436,400 & 379,600 & 439,300 & 180,900 \\
\hline & 232 & 214 & 213 & 240 & 226 & 217 & 226 & 226 \\
\hline \multirow[t]{2}{*}{09216000} & 68,240 & 75,870 & 92,490 & 97,690 & 102,300 & 92,440 & 93,760 & 75,200 \\
\hline & 2,252 & 1,727 & 1,057 & 1,537 & 1,383 & 1,420 & 1,563 & 2,186 \\
\hline \multirow[t]{2}{*}{09216050} & $-\cdots$ & -- & --- & 180,100 & 199,500 & 163,600 & 169,100 & 136,400 \\
\hline & --- & --- & ---- & 2,274 & 2,226 & 2,075 & 2,279 & 2,934 \\
\hline \multirow[t]{2}{*}{09217000} & 456,000 & 648,600 & 768,100 & 574,900 & 646,200 & 568,600 & 640,500 & 306,700 \\
\hline & 353 & 284 & 280 & 344 & 315 & 307 & 313 & 452 \\
\hline \multirow[t]{2}{*}{09222000} & 96,450 & 130,200 & 126,400 & 143,300 & 136,500 & 135,200 & 88,960 & 27,690 \\
\hline & 716 & 669 & 648 & 670 & 644 & 574 & 895 & 1,533 \\
\hline \multirow[t]{2}{*}{09224700} & 134,500 & 273,800 & 244,900 & 228,700 & 219,900 & 214,700 & 191,200 & 33,580 \\
\hline & 565 & 463 & 475 & 563 & 533 & 516 & 630 & 1,175 \\
\hline \multirow[t]{2}{*}{09229500} & 54,680 & 70,230 & 50,820 & 82,950 & 49,120 & 71,850 & 35,710 & 18,090 \\
\hline & 649 & 527 & 577 & 530 & 659 & 463 & 784 & 942 \\
\hline \multirow[t]{2}{*}{09234500} & 986,900 & 683,000 & $1,260,000$ & $1,422,000$ & 977,800 & $1,316,000$ & $1,384,000$ & $1,340,000$ \\
\hline & 466 & 472 & 464 & 495 & 506 & 524 & 509 & 477 \\
\hline
\end{tabular}




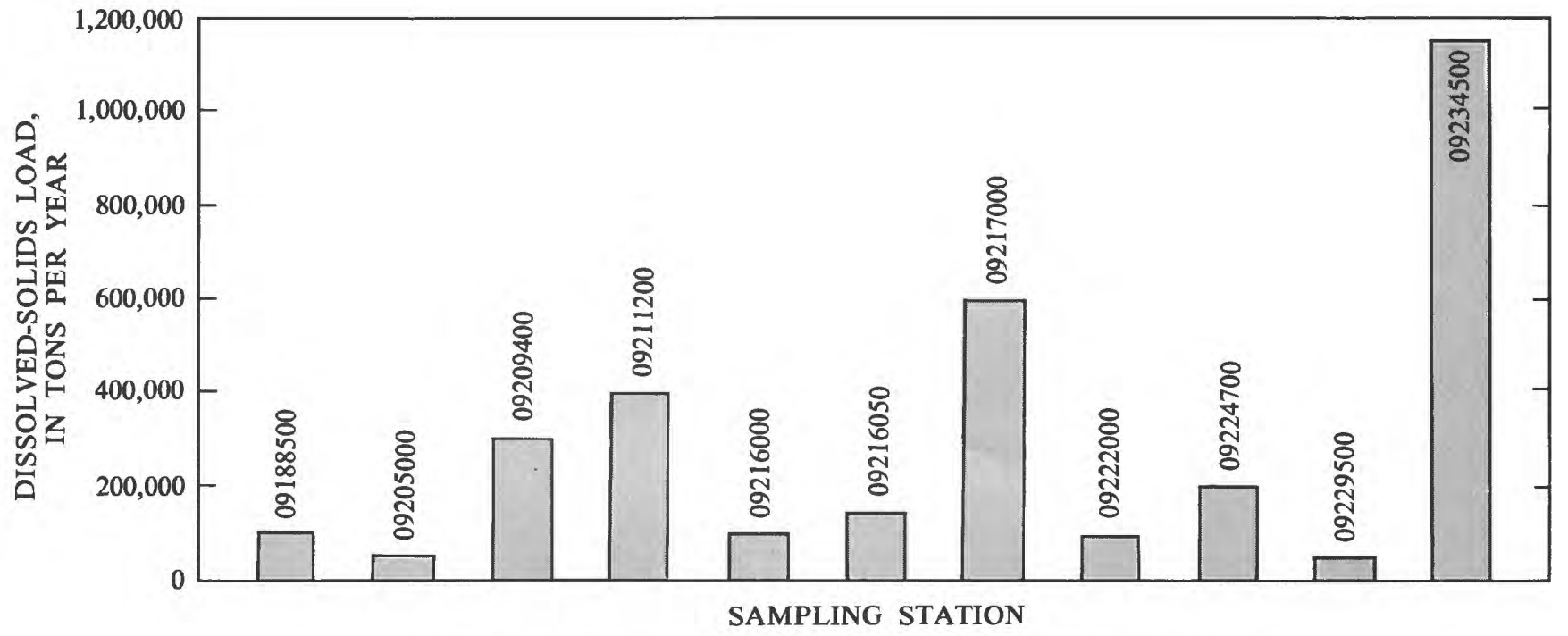

Figure 2.1-1 Average dissolved-solids loads, 1970-77 water years.

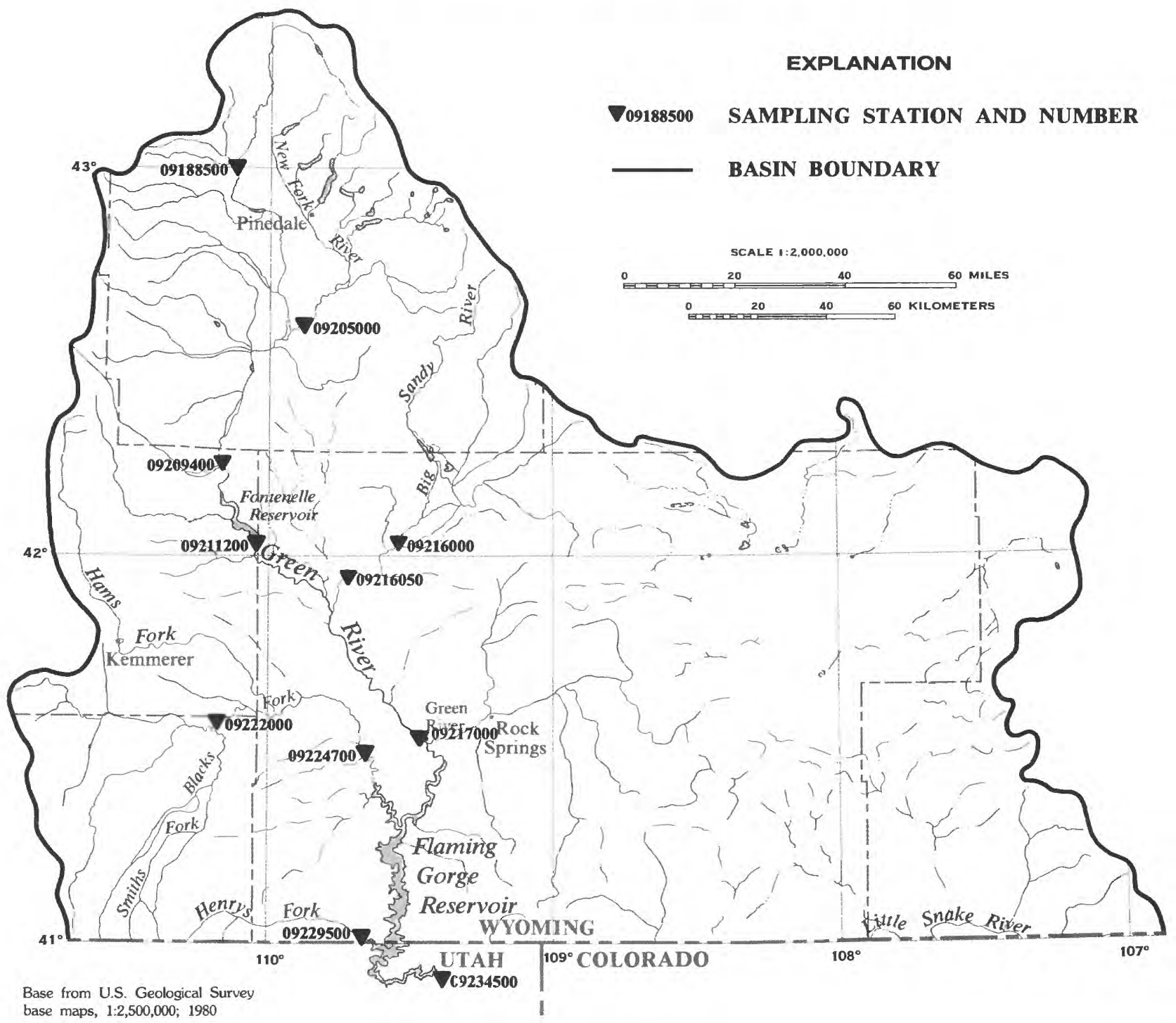

Figure 2.1-2 Location of sampling stations. 


\subsection{SALINITY--Continued \\ 2.2 Estimating Effects of Water Development}

\section{Probable effects of alternative development plans on surface-water salinity may be evaluated by comparing estimated changes in dissolved-solids concentrations downstream from proposed development.}

Consumptive use of surface water for energyrelated development in southwestern Wyoming (such as diversions for powerplants, coal-slurry pipelines, and municipalities) is likely to have a greater effect on surface-water salinity than the actual mining of energy minerals (DeLong, 1978). Existing and planned mines in the Green River basin lie mainly in plains areas characterized by intermittent and ephemeral streams. Mining plans commonly assume total consumption of water within the area of the mine during both mining and reclamation. Even without total consumption, mines in the basin would not be persistent sources of salinity owing to the minimal precipitation and subsequent runoff from the mining areas. Unusually intense storms could cause saline runoff, but such storms are localized; and the runoff would not have a significant effect on major drainages.

Water would most likely be diverted from major perennial streams of the basin. The probable effect of proposed diversions made from different points within the stream system may be evaluated by es- timating dissolved-solids concentrations at each point of diversion, computing the dissolved-solids load removed by diversion, and superimposing the changes in streamflow and dissolved-solids loads on estimates made for common downstream locations.

For example, a constant diversion of 20 cubic feet per second from the Big Sandy River at Gasson Bridge without return flow could potentially decrease dissolved-solids concentrations downstream in the Green River at Green River, Wyoming by as much as 13 percent during the winter months (fig. 2.2-1). Potential decreases in concentrations during the remainder of the year generally would be less than 2 percent. Concentrations would decrease downstream in the Green River because the concentrations in the Big Sandy River at the point of diversion are greater than the concentrations in the Green River. Conversely, an equivalent diversion from the mainstem of the Green River upstream from the Big Sandy River could result in a slight increase in dissolved solids downstream at the town of Green River. 

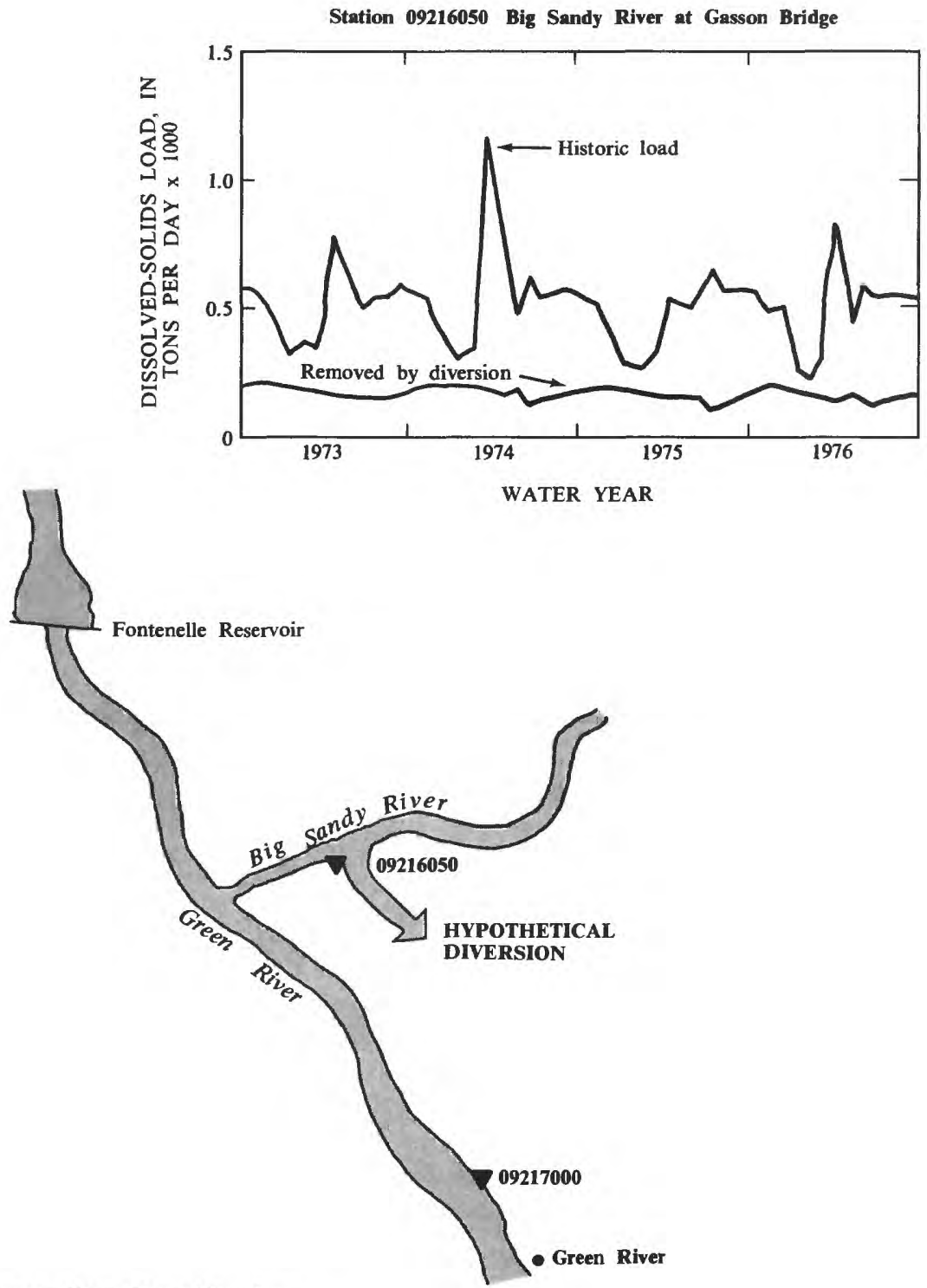

Station 09217000 Green River near Green River, Wyoming

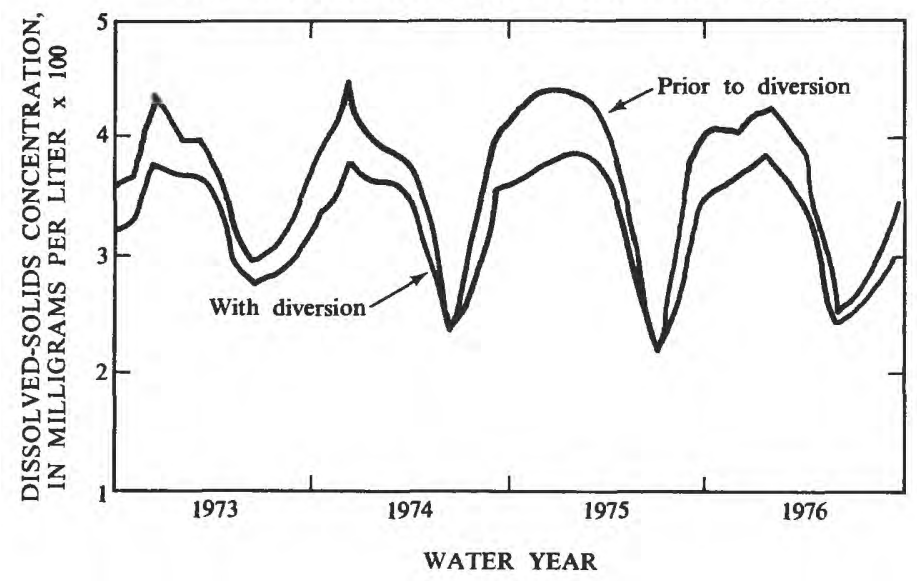

Figure 2.2-1 Estimation of downstream effect on dissolved-solids concentrations of a hypothetical diversion from the Big Sandy River. 


\subsection{SALINITY--Continued \\ 2.3 Dissolved-Solids Concentrations in Ephemeral and Intermittent Streams}

\section{Unlike the dilution effect that overland runoff has on the baseflow of most perennial streams, runoff in ephemeral and intermittent streams is enriched by the "flushing" of salts from normally dry channels and other basin surfaces.}

The variable nature of flow in ephemeral and intermittent streams significantly affects corresponding water quality. During periods of infrequent precipitation and runoff, salts accumulate in channels and on other basin surfaces. Concentration of dissolved solids in the downstream edge of runoff reflects the availability of readily soluble salts. Dissolved-solids concentration continues to increase during runoff until salts are sufficiently flushed from inundated surfaces allowing the dilution effect of continued runoff to prevail (fig. 2.3-1).

The composite effect of overland runoff on perennial streams in the Green River basin, as shown by DeLong (1977), is dilution. Headwaters of most perennial streams within the basin are in mountainous areas characterized by greater relative precipitation and runoff. Dissolved-solids concentrations in overland runoff from these areas typically are less than the base-flow concentrations of recipient peren- nial streams. Dissolved-solids concentrations typically are greater in snowmelt runoff from lower elevations characterized by ephemeral and intermittent streams than in snowmelt runoff from the mountainous areas. The fact that snowmelt runoff at lower elevations generally precedes that from the mountainous areas contributes to a seasonal trend in the relation between streamflow and dissolved-solids concentration of perennial streams (DeLong, 1977).

Data to illustrate the enrichment effect and flushing action were collected along Lost Creek (fig. 2.3-2) on April 1-2, 1976 (fig. 2.3-3). A plot of dissolved-solids concentration versus downstream distance shows the flushing action typical of the first flow of snowmelt runoff (fig. 2.3-4). The greatest concentration on both days was observed near the downstream edge of the water as it moved down the previously dry channel.

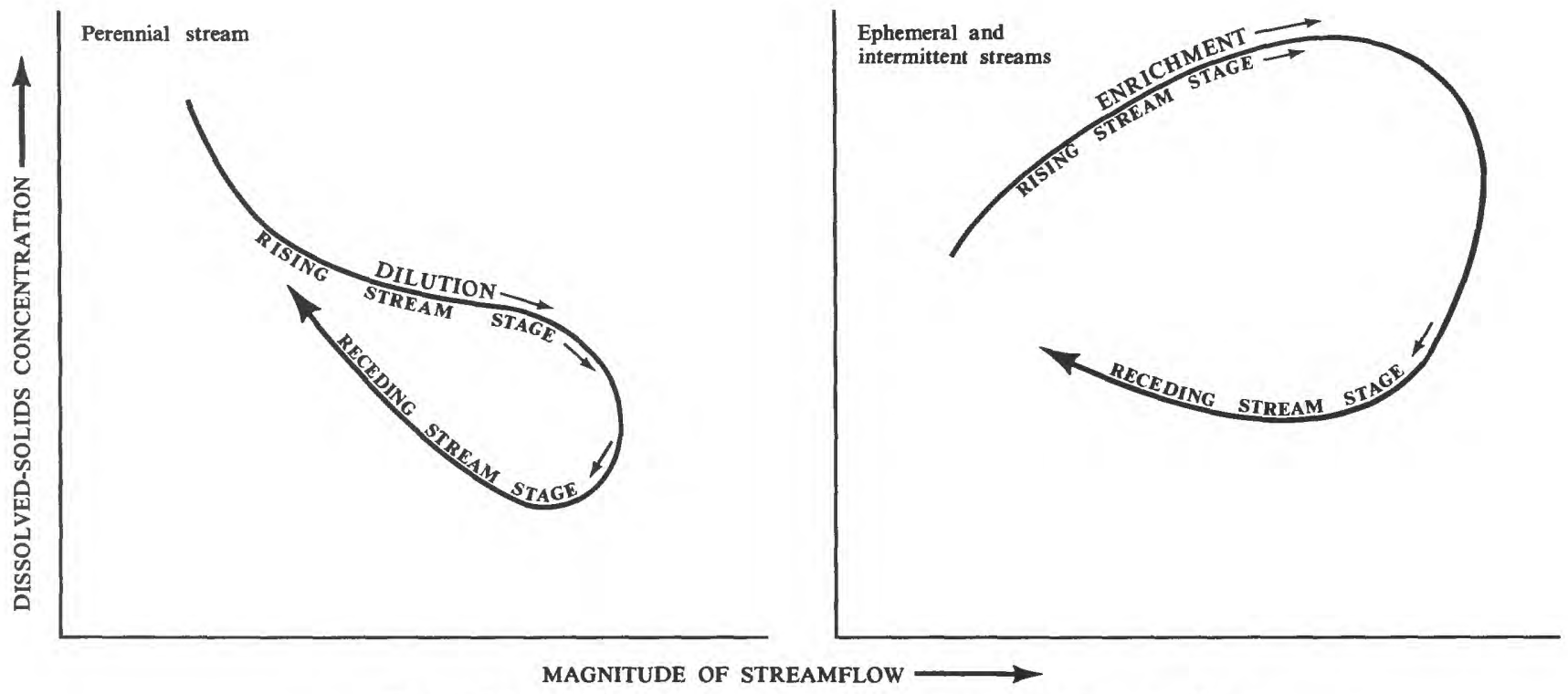

Figure 2.3-1 Comparison between dilution and enrichment effects. 


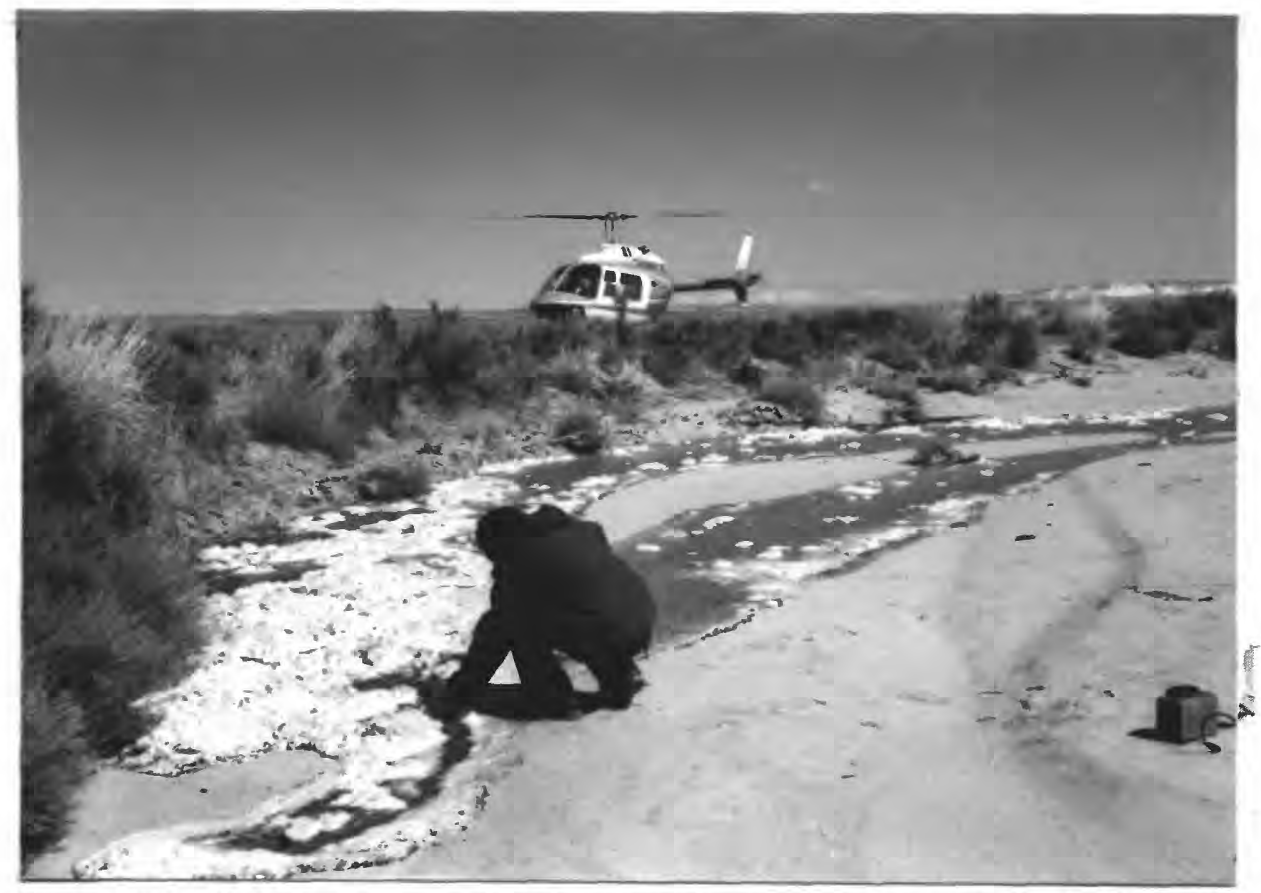

Figure 2.3-3 Sampling leading edge of snowmelt runoff in Lost Creek, April 1, 1976. 


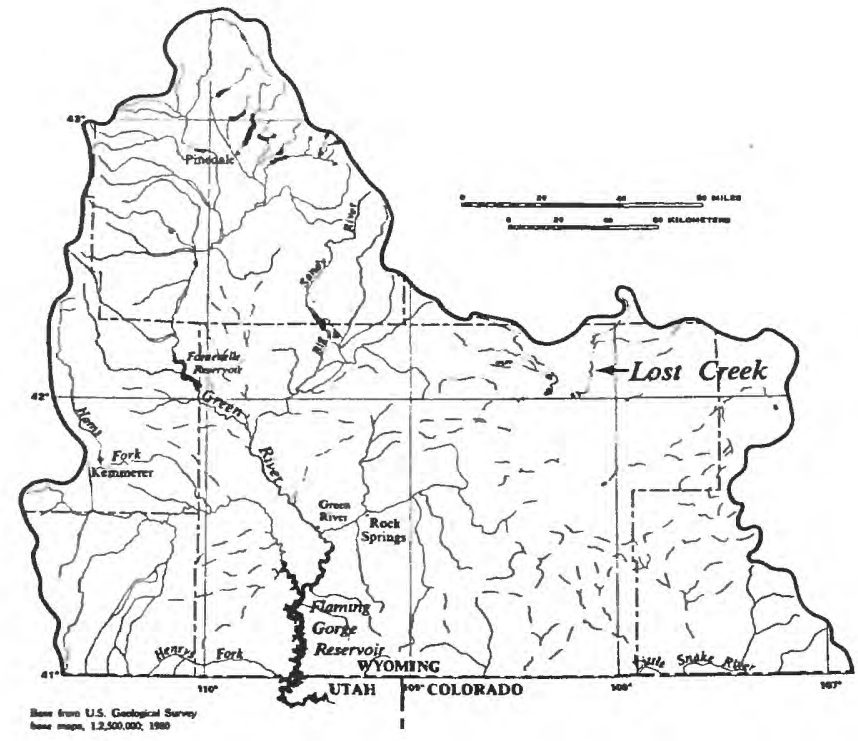

EXPLANATION

BASIN BOUNDARY

Figure 2.3-2 Location of Lost Creek.

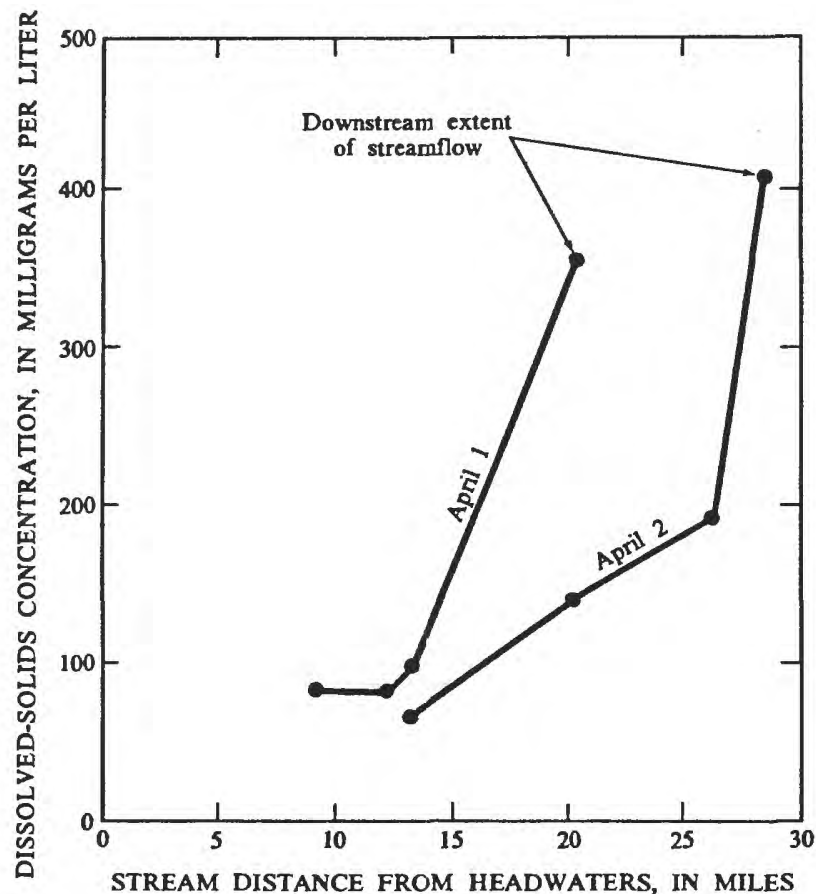

Figure 2.3-4 Flushing of Lost Creek Channel by snowmelt runoff, 1976. 


\subsection{SALINITY--Continued \\ 2.4 Relative Calcium, Sulfate, and Sodium Concentrations}

\section{Relative concentrations of calcium in streams and springs in the Green River basin generally are controlled by solubility, whereas sulfate and sodium concentrations generally reflect sources.}

Chemical equilibrium calculations (similar to those demonstrated by Hem, 1966, p. 64-77; 1970, p. 250-255) indicate that most stream water in the Green River basin is saturated or nearly saturated with respect to calcite (calcium carbonate). A similar condition exists in the major rivers of Russia (Alekin and Morichevea, 1957) as reported by Hem (1961, p. 14-15). Because calcite saturation typically persists in the study area from near the headwaters through downstream reaches, stream water dissolves very little calcium carbonate en route. In fact, calcium dissolved from other sources such as calcium sulfate would tend to precipitate as calcium carbonate. Dissolution of calcium sulfate and subsequent precipitation of calcium carbonate is hypothesized to account for a relative increase of sulfate concentration in Flaming Gorge Reservoir (Bolke, 1979, p. 3234). The streams in the study area, however, are not saturated with respect to other ions. Controlled largely by availability and dissolution rates, concentrations of these ions continue to increase downstream (fig. 2.4-1). Initially large relative sulfate concentrations in the Green River are caused by sulfate concentrations of springs tributary to the head waters. Dilution by less concentrated tributaries causes a short-lived decrease in relative sulfate concentration that gradually is overcome by a continued increase in the absolute sulfate concentration downstream. The downstream trend of increasing relative concentrations of sulfate, sodium, or both with an overall increase in dissolved-solids concentration is typical of all streams sampled within the basin.

Analyses of water samples obtained from springs exhibit a similar trend (fig. 2.4-2); the largest concentrations of sulfate and sodium occur in samples with the largest dissolved-solids concentrations. 


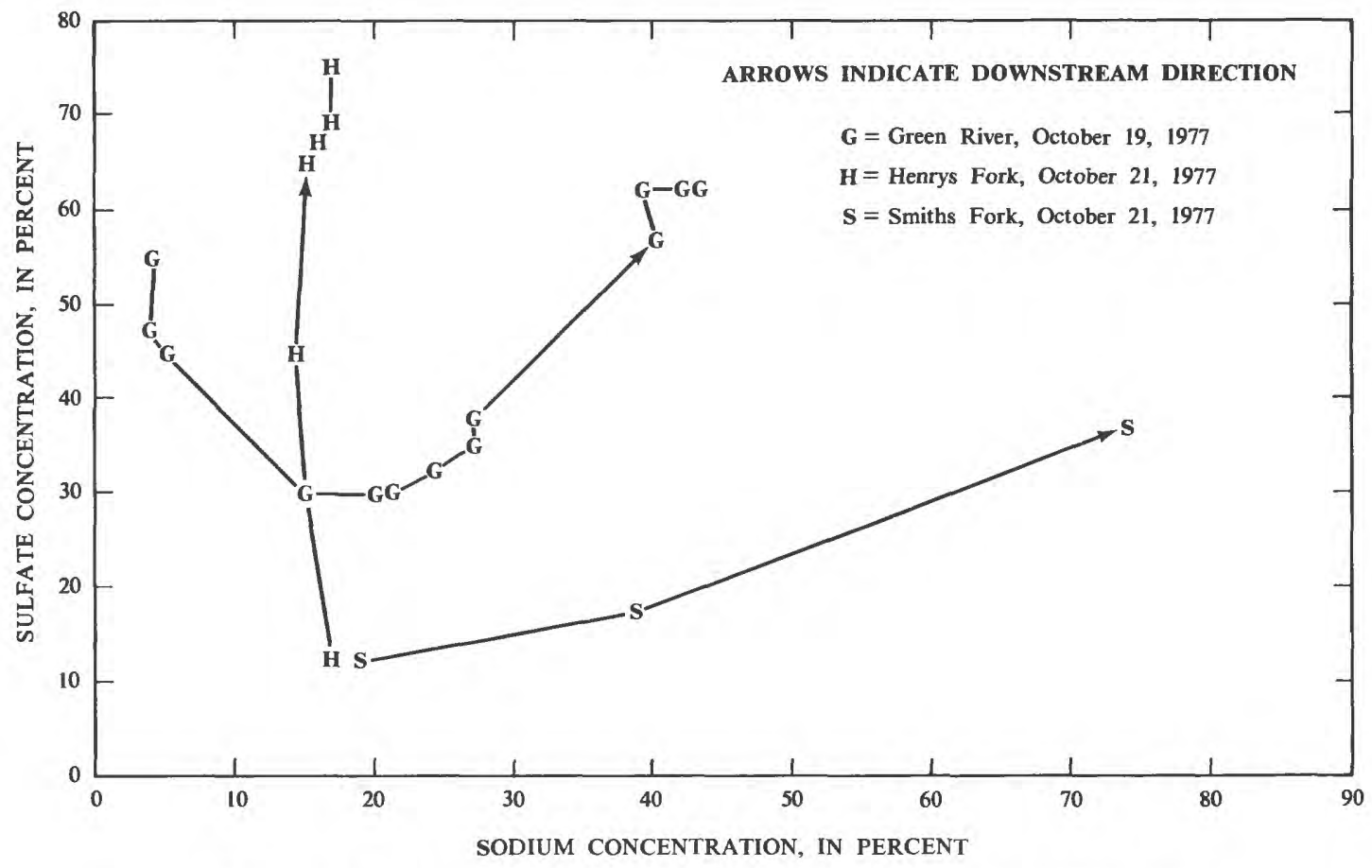

Figure 2.4-1 Downstream increase in sulfate and sodium concentrations.

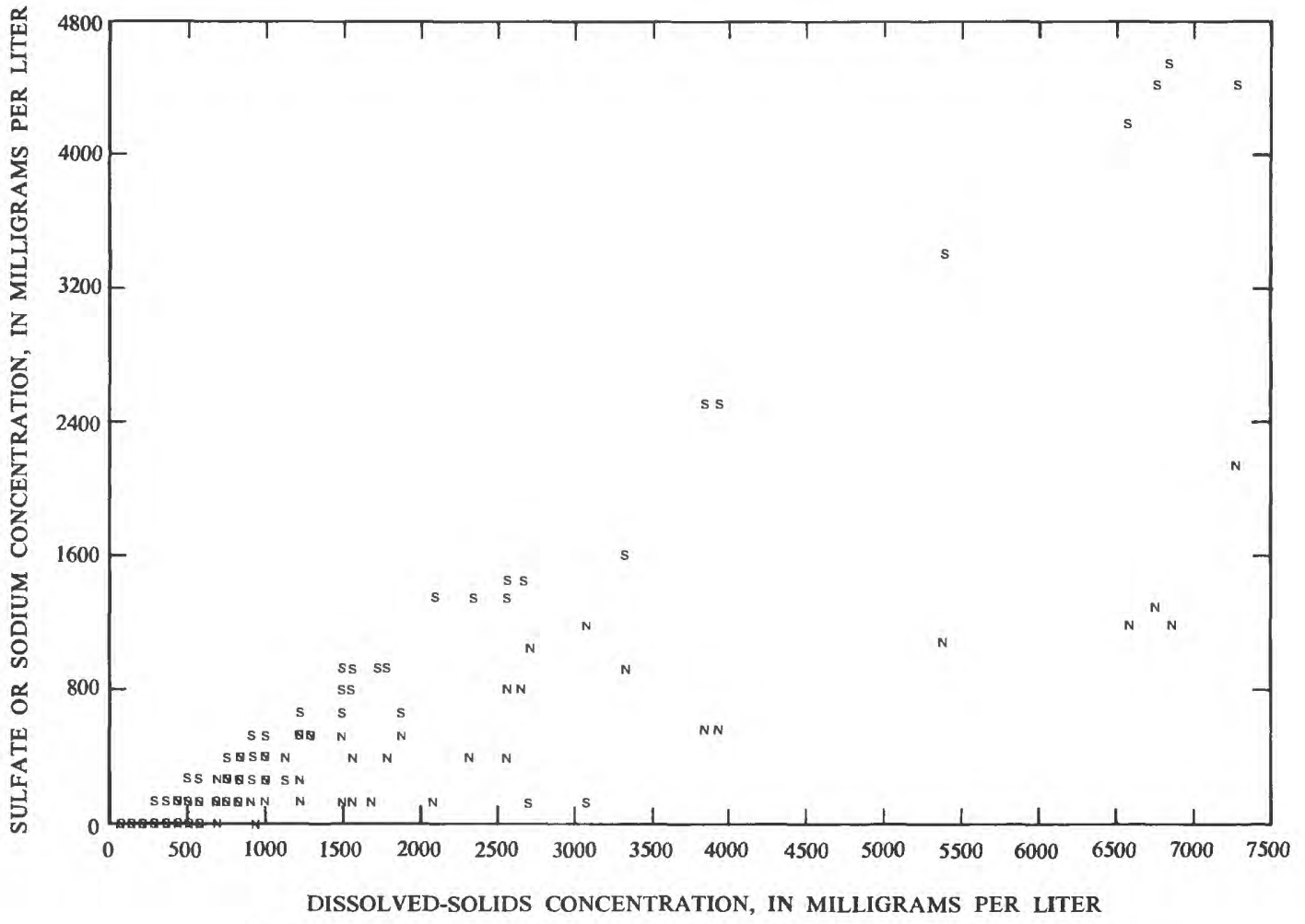

Figure 2.4-2 Relation of sulfate (S) and sodium ( $N$ ) concentrations to dissolved-solids concentrations in samples from springs.

\subsection{SALINITY--Continued}

2.4 Relative Calcium, Sulfate, and Sodium Concentrations 


\subsection{SALINITY--Continued \\ 2.5 Chemical Composition of Water in Samples from Springs}

\section{Variation of chemical composition and overall concentrations of water from springs is as great within individual geologic units as it is between different geologic units.}

Water samples of springs flowing from the same geologic unit did not exhibit a characteristic chemical composition. The range of overall concentrations (fig. 2.5-1) and chemical composition (fig. 2.5-2) was as great in samples collected from springs scattered areally over a particular geologic unit as it was between spring samples collected from different geologic units. It generally would not be possible to determine the geologic unit from which a spring sample was collected by chemical composition and overall concentration.

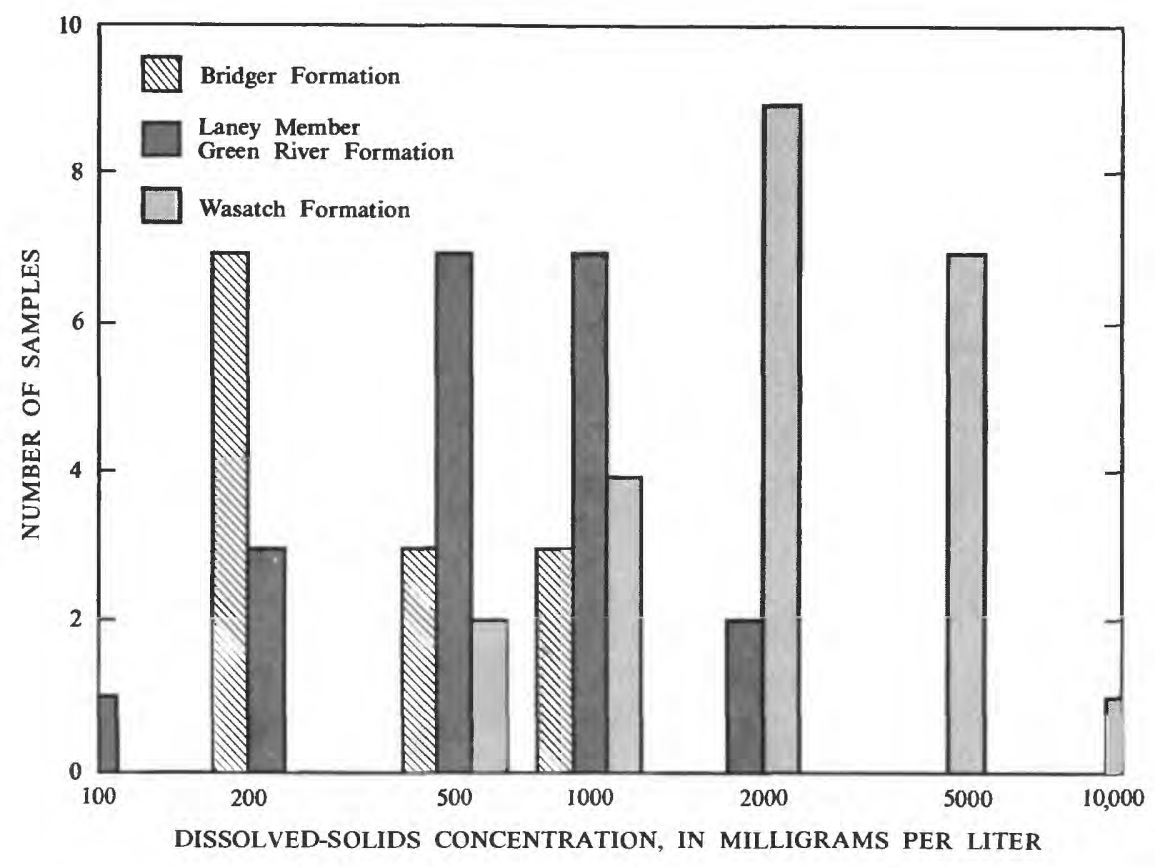

Figure 2.5-1 Dissolved-solids concentrations in samples collected from springs flowing from the Bridger and Wasatch Formations and the Laney Member of the Green River Formation. 

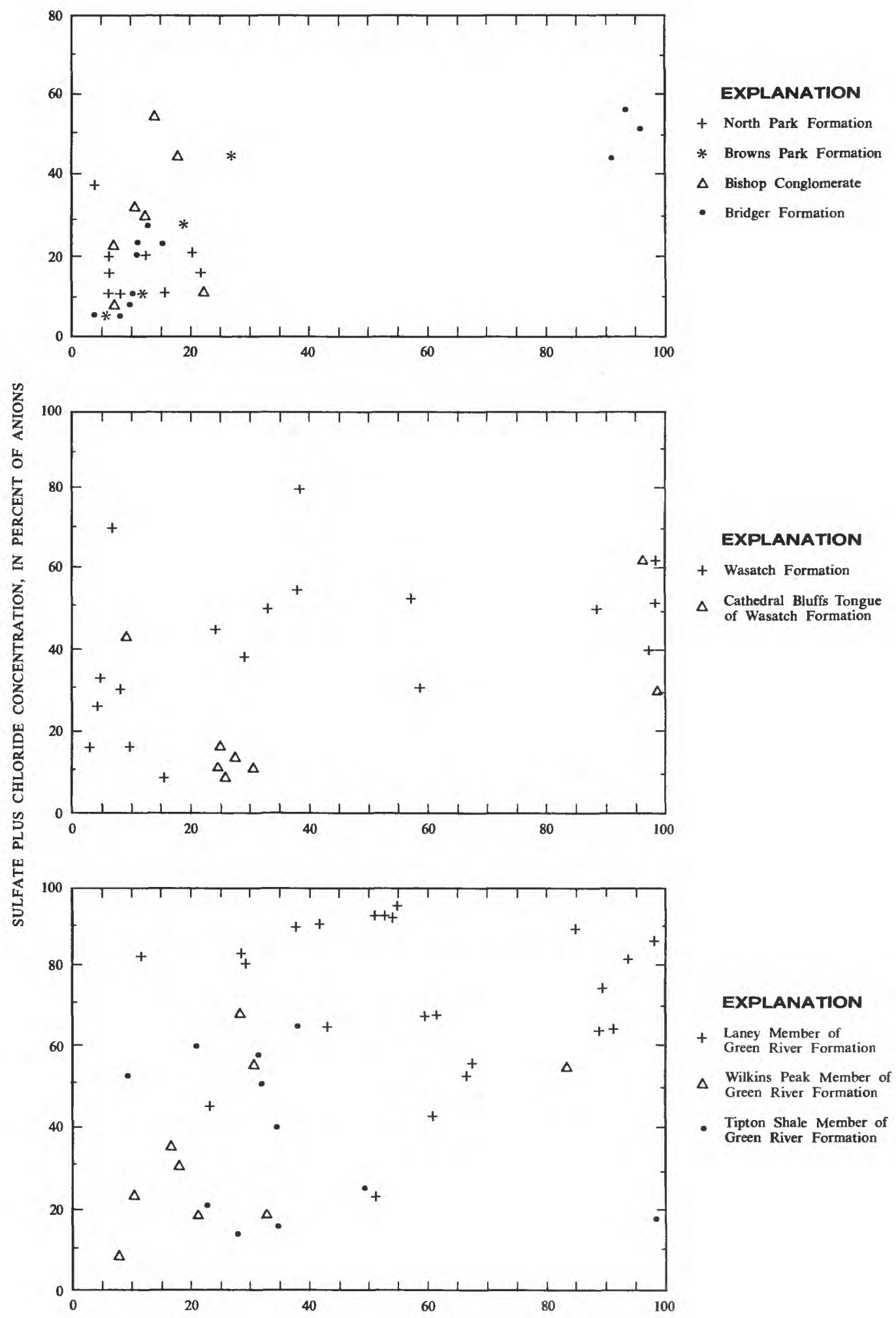

SODIUM PLUS POTASSIUM CONCENTRATION, IN PERCENT OF CATIONS

Figure 2.5-2 Relation of sulfate plus chloride concentrations to sodium plus potassium concentrations in samples from springs. 


\subsection{PHOSPHORUS}

3.1 Effect of Reservoirs

\section{Phosphorus is removed from the Green River as the water passes through Fontenelle and Flaming Gorge Reservoirs.}

Control of phosphorus in surface waters of the Green River basin has become an important waterquality issue primarily as a result of eutrophication studies in the basin and increasing algal growth in Flaming Gorge Reservoir. The reservoir has been classified eutrophic at points within the Blacks Fork and Green River arms and at a point downstream from their confluence (U.S. Environmental Protection Agency, 1977, p.12). Algal blooms in the arms of the reservoir have grown increasingly larger during the last decade (CH2M Hill, 1977, p.13).

Estimating present phosphorus loading is a useful step in assessing probable effects of future development and controls on eutrophication. The effectiveness of Fontenelle and Flaming Gorge Reservoirs as phosphorus traps is readily apparent in estimates of loads and concentrations at adjoining stations (figs. 3.1-1 and 3.1-2). Estimates of phosphorus loads contributed to the reservoirs from direct runoff and other tributaries would be necessary to estimate phosphorus storage rates in the reservoirs. However, considering the quantities of phosphorus from the Green River alone that may have been stored in the reservoirs since their completions, it seems unlikely that algal growth would be a simple function of phosphorus loading in any one season. Further study would be necessary to quantify dominant transport and growth mechanisms in the reservoirs. Results would be useful in examining feasibility of various control measures and effects of alternative development plans.

The increase in phosphorus load from station 09217000, Green River near Green River, Wyoming, to station 09217010, Green River below Green River, Wyoming is presumably a result of inflow between the two stations. Bitter Creek joins the Green River between the two stations, and sewage effluent is contributed both through Bitter Creek and directly to the Green River between the two stations.

Average loads (table 3.1-1) and geometric-mean concentrations (table 3.1-2) at individual stations were estimated by methods described in section 5 . Logarithms of measured concentrations and calculated loads were used to transform data to the normal form. All phosphorus concentrations used in this report are total concentrations resulting from analysis of the total water-sediment mixture in the samples.

Table 3.1-1 Average total phosphorus loads, 1974-78 water years.

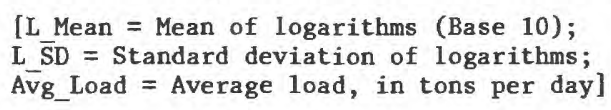

\begin{tabular}{lrrr}
\hline Station & \multicolumn{1}{c}{ L_Mean } & \multicolumn{1}{c}{ L_SD } & Avg_Load \\
\hline 09188500 & -1.981486 & 0.651740 & 0.031 \\
09205000 & -1.838354 & .707267 & .053 \\
09209400 & -1.612998 & .882251 & .180 \\
09211200 & -1.603068 & .551888 & .055 \\
09214500 & -2.946421 & 1.156198 & .027 \\
09216000 & -2.794096 & .802085 & .008 \\
09216050 & -2.270304 & .821662 & .030 \\
09216300 & -1.641843 & .742699 & .095 \\
09217000 & -1.013692 & .627777 & .269 \\
09217010 & -.694740 & .572333 & .473 \\
09222300 & -2.906847 & .607950 & .003 \\
09222400 & -2.360567 & 1.170525 & .121 \\
09224050 & -1.612482 & .413497 & .038 \\
09224450 & -2.523287 & 1.188375 & .107 \\
09234500 & -1.253458 & .556600 & .125
\end{tabular}




\subsection{PHOSPHORUS--Continued \\ 3.2 Relation to Streamflow}

\section{Total phosphorus concentration at some stream sites is related to streamflow.}

Total phosphorus concentration in a stream may vary as a result of changes in streamflow (fig. 3.2-1). Dilution occurs if sources of additional water to the stream contain less phosphorus concentration relative to initial stream concentration. Conversely, enrichment of the stream occurs when additional water contains greater relative concentration. Increasing streamflows accompanied by rising stream stages also may increase total phosphorus concentration by capturing phosphorus previously stored in channels. For example, total phosphorus concentration in Salt Wells Creek, an intermittent plains stream at the southern end of the Green River basin, is directly related to sediment concentration (Lowham and others, 1982).

Total phosphorus concentration in the Green River within Wyoming was not found to be related to magnitude of streamflow. In the Green River, as in most of its major tributaries, the lack of relation between total phosphorus and streamflow may be thought of as an averaging of dilution and enrichment effects. It should also be noted that phosphorus concentration is affected by its extensive use in biological cycles as a nutrient. 


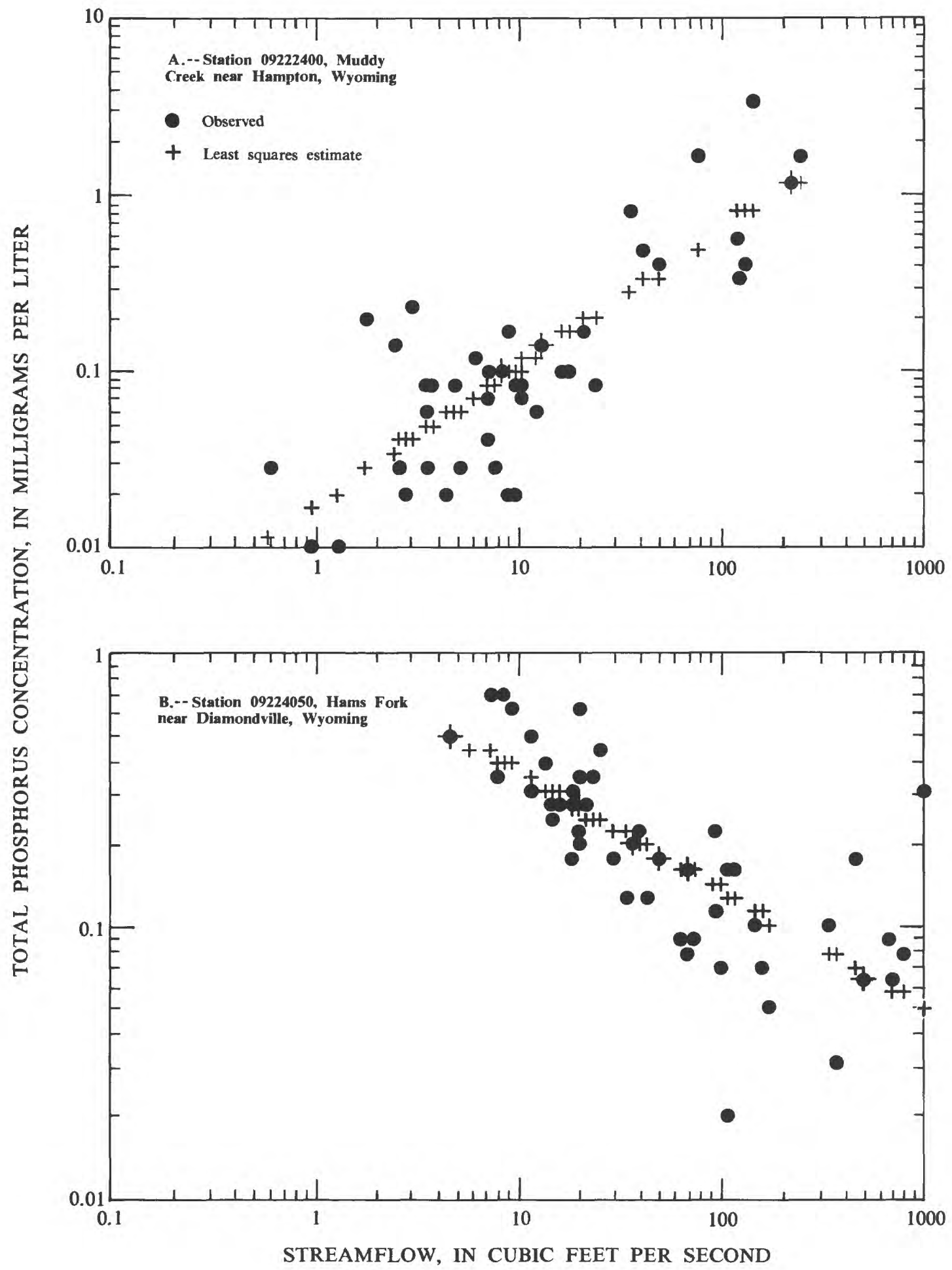

Figure 3.2-1 Relation of total phosphorus concentrations to streamflow. 


\subsection{TRACE ELEMENTS}

\section{Trace-element concentrations in many of the samples analyzed were less than detection limits.}

Trace elements, as the term implies, normally are found at minute or "trace" concentrations in natural water. Consequently, trace-element concentrations are reported in micrograms per liter as opposed to the major constituents in water which are reported in milligrams per liter. As shown in the bar graph (fig. 4.0-1), a significant number of the samples contained concentrations less than prevalent analytical detection limits. Detection limits may vary among elements or analytical procedures or both. Trace-element concentrations summarized in this report were determined by atomic-absorption spectrophotometry (Skougstad and others, 1979). In general, detection limits range from 1 to 10 micrograms per liter for the dissolved analyses and from 1 to 100 for the total analyses. Although the exact concentration of a particular constituent in a sample may be less than detection limits, the sample can still be used in statistical analysis. The knowledge that the concentration is less than a certain value is useful information, obtained with considerable effort and expense. Section 5.0 describes the method used in this report to include data with values less than detection limits in the determination of means and standard deviations.

What is a typical value of total arsenic concentration? In table $4.0-1$, it can be seen that geometric means of total arsenic concentrations at water-quality measurement sites differ by an order of magnitude. Numbers in columns represented by downstream-station numbers (09209400, for example; fig.
4.0-2) are geometric means of samples collected periodically at the same site. The columns headed "Misc-SW" (miscellaneous surface water) and "Springs" represent geometric means of samples collected one per site. Geometric means are used, rather than arithmetic means, because they provide a better measure of central tendency. Frequency distributions of logarithms of the data show more symmetry than do frequency distributions of the untransformed data. Summary statistics from which the table of geometric means was derived are tabulated in section 8.0 of this report.

\begin{tabular}{ll}
\multicolumn{2}{c}{ Abbreviations } \\
AS & Arsenic \\
BA & Boron \\
CD & Barium \\
CR & Cadmium \\
CU & Chromium \\
DI & Copper \\
FE & Dissolved \\
I & Iron \\
MN & Lithium \\
MO & Manganese \\
NI & Molybdenum \\
PB & Nickel \\
SE & Lead \\
TO & Selenium \\
T & Total \\
ZN & Vanadium \\
& Zinc
\end{tabular}

Table 4.0-1 Geometric means of trace-element concentrations, in micrograms per liter.

\begin{tabular}{|c|c|c|c|c|c|c|c|c|c|c|c|c|c|c|c|c|c|c|c|c|}
\hline \multirow[b]{2}{*}{ Elewent } & \multicolumn{18}{|c|}{ Station nember } & \multirow[b]{2}{*}{ 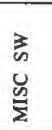 } & \multirow[b]{2}{*}{ 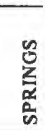 } \\
\hline & 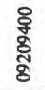 & 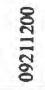 & 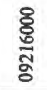 & 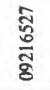 & $\frac{\sqrt{n}}{\frac{\sigma}{\delta}}$ & 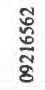 & 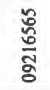 & $\frac{0}{n}$ & $\frac{\circ}{\frac{\hbar}{6}}$ & $\frac{\frac{0}{0}}{\frac{0}{\circ}}$ & 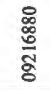 & $\frac{\text { ్ㅇ }}{\frac{5}{\delta}}$ & $\frac{}{\frac{2}{2}}$ & 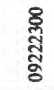 & 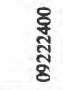 & 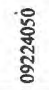 & $\begin{array}{l}\text { \&్ల } \\
\text { స్ } \\
\text { ઠ }\end{array}$ & 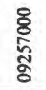 & & \\
\hline Arsenic, dissolved & - & - & 2 & - & 1 & - & - & 1 & - & 1 & 8 & 1 & 1 & 1 & 2 & 1 & 1 & 2 & 1 & \\
\hline Arsenic, tota & 1 & 1 & 3 & 5 & 4 & 2 & 3 & 2 & 23 & 4 & 12 & 1 & 1 & 2 & 3 & 1 & 6 & 2 & 7 & 1 \\
\hline Barium, dissolve & - & - & - & - & - & - & - & - & - & - & - & - & $=$ & - & - & - & - & - & 87 & 10 \\
\hline Barium, total & - & - & - & - & - & - & - & - & - & - & - & - & - & - & - & - & - & - & 273 & 195 \\
\hline Boron, dissolve & - & - & - & 103 & 217 & 482 & 145 & 117 & 605 & 1,870 & 448 & 58 & 66 & 1,710 & 1,240 & 49 & 162 & - & 59 & 103 \\
\hline Cadmium, dissolved & 1 & 1 & 2 & - & - & 2 & 1 & 1 & - & 2 & 1 & 1 & 1 & 1 & 1 & 1 & 2 & & 0 & 0 \\
\hline Cadmium, total & 6 & 9 & $\overline{7}$ & - & 6 & 7 & 7 & . & 5 & $=$ & 6 & 6 & 5 & 6 & 5 & & 6 & & 3 & 1 \\
\hline Chromiun, dissolve & - & - & - & - & - & - & - & - & - & 10 & 6 & - & - & - & $=$ & - & - & & & - \\
\hline Chromiun, total & 5 & - & 8 & 21 & 7 & 9 & 8 & - & 37 & 14 & 9 & - & 5 & 6 & 9 & 6 & 8 & - & 17 & 3 \\
\hline Copper, dissove & 2 & 2 & 3 & 2 & 3 & 3 & 1 & 1 & $\because$ & 3 & 3 & 2 & 1 & 4 & 2 & 1 & 4 & 1 & 1 & 1 \\
\hline Copper, t & 14 & 11 & 13 & 19 & 13 & 14 & 13 & - & - & 14 & 17 & 16 & 8 & 12 & 12 & 8 & 14 & - & 18 & 2 \\
\hline & 25 & 21 & 20 & 104 & 69 & - & 75 & 62 & 45 & 80 & 69 & 21 & 21 & 58 & 65 & 43 & 74 & & 58 & 60 \\
\hline Lead, d & 1 & 2 & 2 & - & - & 3 & 1 & 2 & - & 4 & 3 & 1 & 3 & - & 3 & - & 2 & 1 & 1 & 1 \\
\hline Lead & 75 & - & 63 & - & 47 & 35 & 34 & - & 93 & 62 & 55 & - & - & 39 & 46 & & 66 & & 34 & 6 \\
\hline ssolved & 6 & 5 & 35 & - & 63 & 213 & 105 & 50 & - & 381 & 100 & 9 & 10 & 78 & & 10 & & - & 43 & 21 \\
\hline & 9 & 8 & 37 & 43 & 63 & 15 & 42 & 60 & 222 & 393 & 103 & 12 & 12 & & 129 & 12 & 93 & & & 19 \\
\hline , di & 8 & 8 & 14 & 24 & 14 & 261 & 165 & 116 & - & 910 & 168 & 7 & 0 & 30 & 15 & 51 & 129 & 26 & 12 & 24 \\
\hline M & 1 & - & 7 & - & 10 & 7 & 5 & - & - & 9 & 2 & 1 & 2 & & & - & 6 & - & 2 & 1 \\
\hline enesen & 2 & 1 & 7 & 2 & 10 & 5 & 6 & 4 & 5 & 9 & 4 & 1 & 2 & 14 & 10 & & 6 & - & 3 & 5 \\
\hline & 2 & 2 & 1 & - & 3 & & - & - & $=$ & 1 & 5 & 2 & 2 & 8 & & 2 & 4 & - & & 0 \\
\hline total & 24 & - & 33 & 25 & 23 & 25 & 17 & - & 68 & 50 & 29 & - & - & 27 & 25 & - & 24 & - & 60 & 11 \\
\hline solved & - & - & 2 & - & - & 3 & & - & 1 & 1 & - & - & - & 4 & 3 & - & - & - & 1 & 0 \\
\hline Seleniu & - & - & 2 & - & 1 & 3 & - & 1 & 4 & 1 & 1 & - & - & 5 & 2 & - & 1 & - & 2 & 0 \\
\hline 1 ved & 0 & 1 & 2 & - & $=$ & & - & $=$ & - & 6 & 3 & 0 & 1 & - & 1 & 0 & - & 1 & 1 & 1 \\
\hline Zinc, d & 5 & 5 & $=$ & - & - & $\therefore$ & - & $=$ & $=$ & 22 & 16 & 8 & 9 & 16 & 9 & - & 12 & - & 7 & 11 \\
\hline Zinc, total & 19 & 16 & 29 & 63 & 34 & 40 & 28 & 22 & 256 & 53 & 47 & 15 & 13 & 36 & 31 & 17 & 48 & 10 & 60 & 9 \\
\hline
\end{tabular}




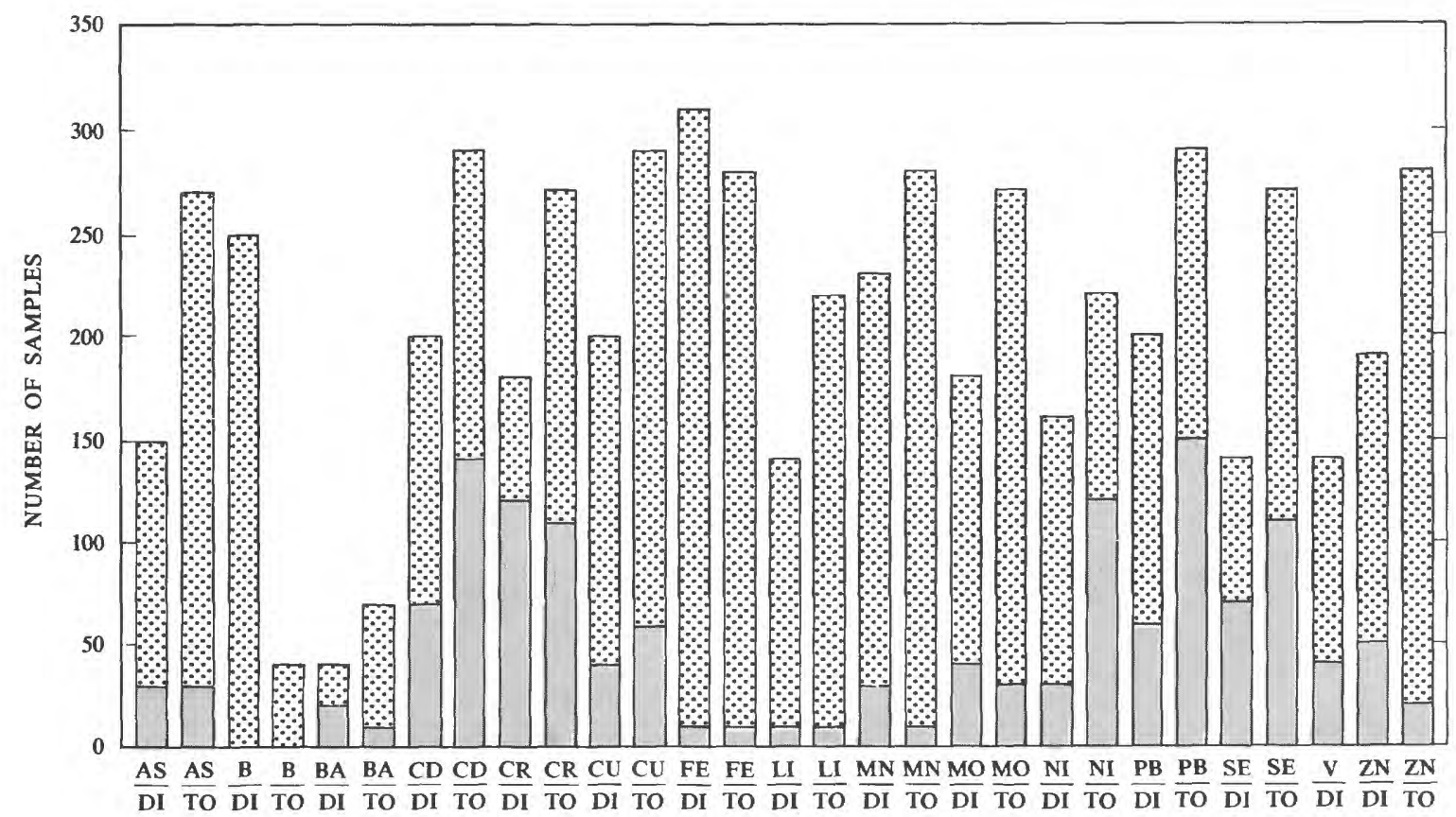

ELEMENTS, DISSOLVED OR TOTAL

Figure 4.0-1 Relation of number of samples with concentrations greater than detection limits (pattern) to number of samples with concentrations less than detection limits (shaded).

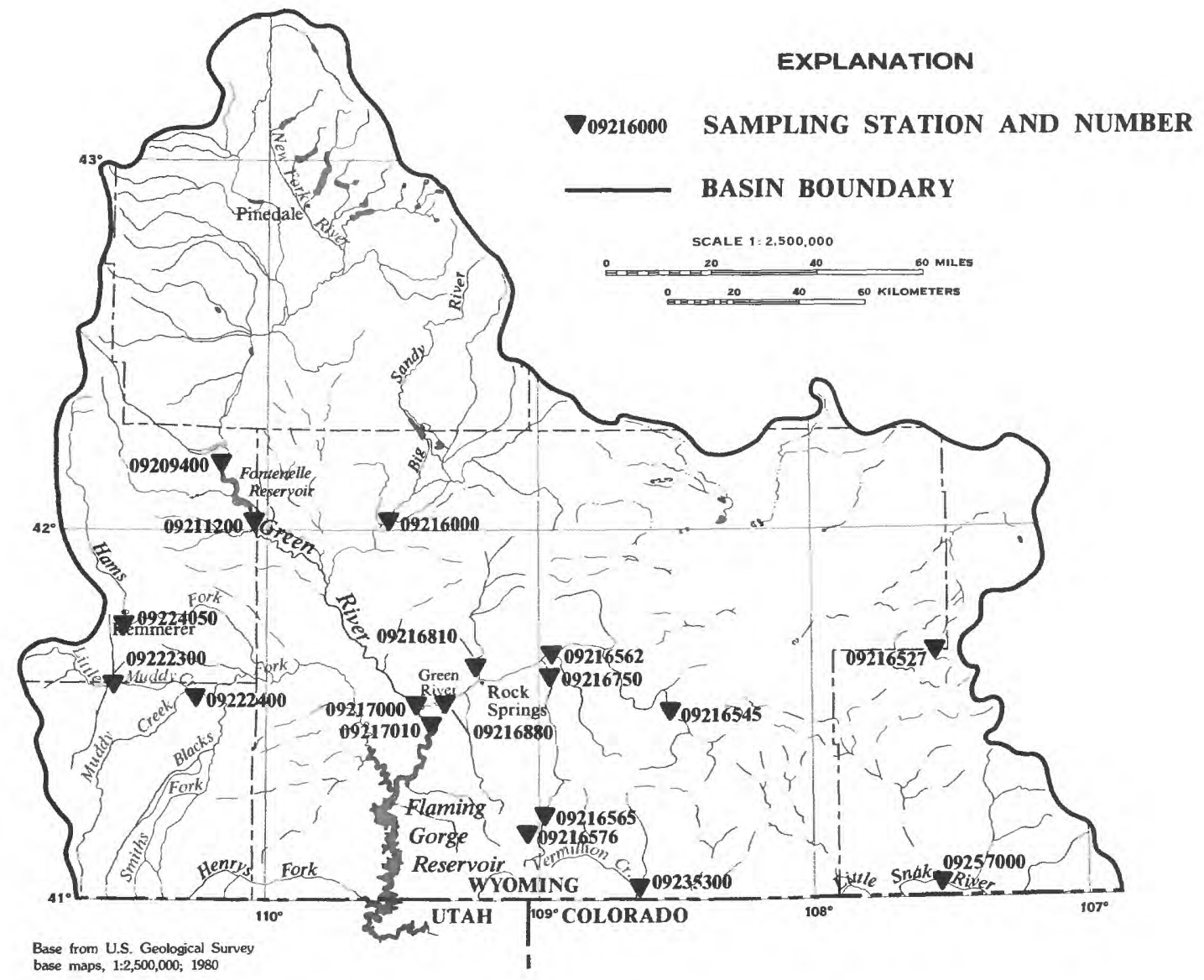

Figure 4.0-2 Location of sampling stations. 


\subsection{ESTIMATION OF MEANS AND STANDARD DEVIATIONS OF DISTRIBUTIONS AFFECTED BY ANAL YTICAL DETECTION LIMITS \\ 5.1 Censored Sample Distributions}

\section{Water-quality data are termed censored data when the constituent concentrations are less than analytical detection limits and cannot be quantified.}

Limited analytical sensitivity often presents a problem in estimating means and standard deviations. Many constituents exist in natural waters at concentrations less than the detection limits of prevalent analytical procedures (fig. 5.1-1). For example, if the detection limit for a particular constituent and attendant analytical procedure is 100 micrograms per liter, concentrations of less than 100 micrograms per liter would be qualified as "F100," "not detected," or simply "0." Data containing such qualified values are referred to as censored. The number of data that are less than the detection limit is known, but their individual magnitudes are unknown. Because of this, averages of the logarithmically transformed or untransformed data cannot be computed directly.

Because censored sample distributions commonly result from the measurement of processes and abundance in nature, many methods have been used to statistically analyze censored distributions. If the qualified values compose less than 20 percent of the data, they may be replaced by arbitrary values directly outside the range of detection of the analytical method used. Seven-tenths of the lower limit of detection was used by Miesch (1976). Methods given by Cohen (1959) and summarized by Miesch (1967) allow statistical analysis of censored-data distributions composed of greater than 20-percent qualified values. Jennings and Benson (1969) used a theorem of conditional probability to estimate probability of occurrence of annual floods from censored data. A ranking procedure, described in section 5.2, was used in this report to calculate cumulative probabilities of concentrations in distributions affected by analytical detection limits. Thus, the number of samples with concentrations less than detection limits and the number and concentrations of samples with concentrations greater than detection limits were used to provide more realistic estimates of means and standard deviations. 


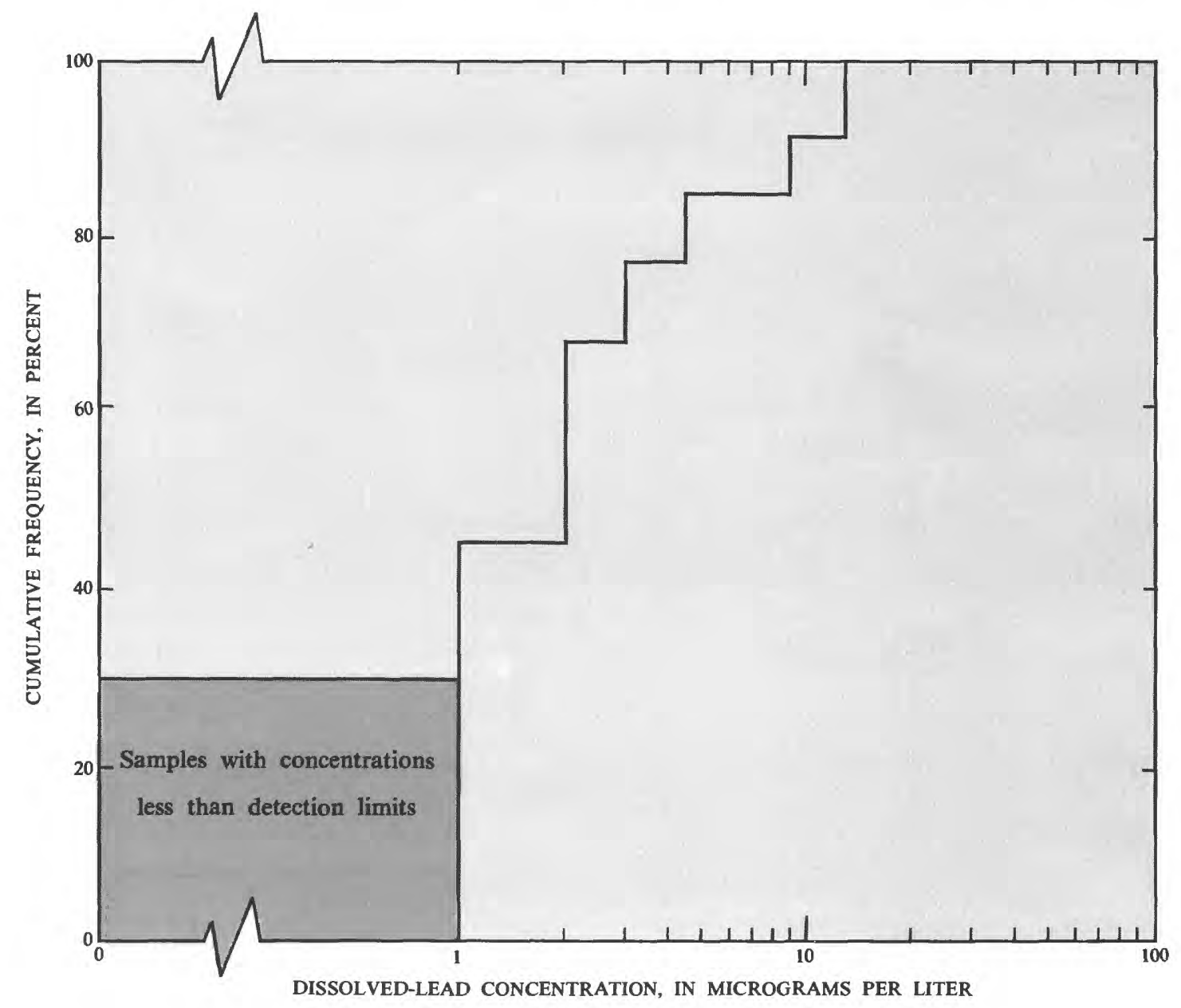

Figure 5.1-1 Dissolved-lead concentration in water samples at station 09217000, Green River near Green River, Wyoming.

\subsection{ESTIMATION OF MEANS AND STANDARD DEVIATIONS OF DISTRIBUTIONS AFFECTED BY ANALYTICAL DETECTION LIMITS \\ 5.1 Censored Sample Distributions}




\title{
5.0 ESTIMATION OF MEANS AND STANDARD DEVIATIONS OF DISTRIBUTIONS AFFECTED BY ANALYTICAL DETECTION LIMITS--Continued \\ 5.2 Geometric Means
}

\author{
Population mean and standard deviation are estimated in this report from \\ censored data distributions by a method that uses the number of data \\ less than detection limits as well as the number and individual magnitudes \\ of data greater than detection limits.
}

Means and standard deviations in this report are estimated from a least-squares fit of data plotted on normal probability paper. When the underlying distribution is normal, data plot as a straight line. Data in this report were transformed to the normal form by using logarithms of the data, and the underlying distributions are referred to as lognormal. The antilog of the mean of the logarithms is an estimate of the geometric mean. The definition of the geometric mean used in this report is the strict mathematical definition: the $n^{\text {th }}$ root of the product of $n$ values.

Cumulative probabilities were estimated from the following equation (Blom, 1958; Barr and others, 1976):

$$
\text { Cumulative probability }=\left(R_{i}-3 / 8\right) \times 100 \div[(n+1 / 4)]
$$

where $\mathrm{n}$ is the total number of samples including qualified values, and $R_{i}$ is rank in ascending order $(1,2,3,, n)$ of the $\mathrm{i}^{\text {th }}$ sample. Qualified values receive ranks lower than the smallest unqualified value. For example, if 20 of 100 samples were below the detection limit for a particular constituent, the 20 qualified values would receive ranks 1-20, and the unqualified value of smallest known magnitude would receive rank 21 .

When logarithms of the known magnitudes are plotted on the vertical coordinate and corresponding cumulative probabilities are plotted on the horizontal coordinate, an estimate of the mean is the value of the vertical coordinate where the fitted line intersects a cumulative probability of 50 percent (Bowker and Lieberman, 1972) as shown in figure 5.2-1. The estimate of standard deviation is the difference on the vertical scale between the points where the fitted line passes through cumulative probabilities of 50 and 84.13 percent. Because of the large quantity of data analyzed in this report, the entire process was computerized using programs written for the Statistical Analysis Systems ${ }^{1}$ (Barr and others, 1976).

1 The use of trade names in this report is for identification only and does not constitute endorsement by the U.S. Geological Survey. 


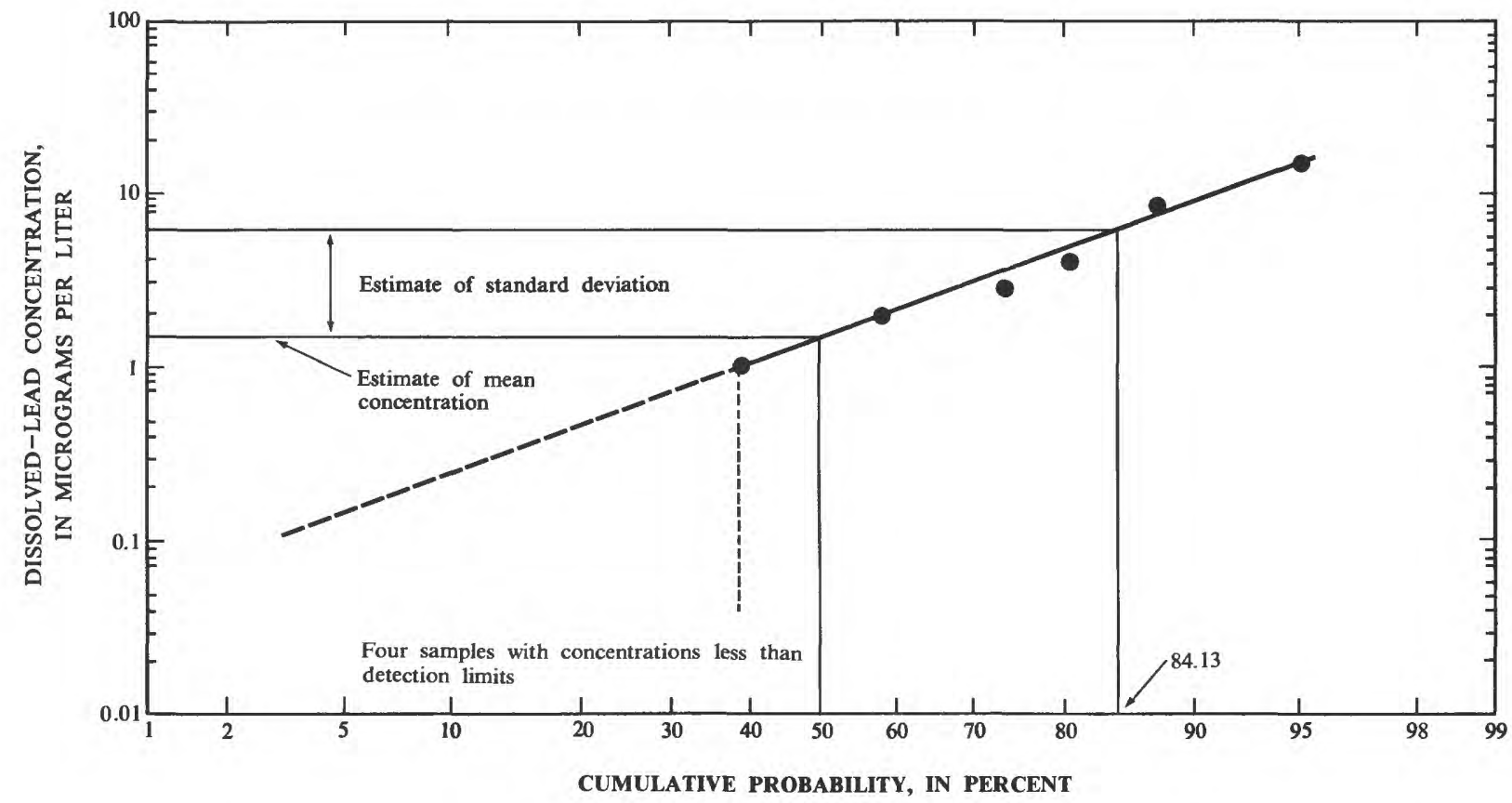

Figure 5.2-1 Determination of mean concentration and standard deviation of a data set containing censored data, station 09217000 , Green River near Green River, Wyoming. 


\subsection{ESTIMATION OF MEANS AND STANDARD DEVIATIONS OF DISTRIBUTIONS AFFECTED BY ANALYTICAL DETECTION LIMITS--Continued 5.3 Arithmetic Means}

\section{In this report, arithmetic means of censored lognormal distributions are estimated from means and standard deviations of logarithms of the data.}

It often is desirable to estimate the arithmetic mean of a data population that is lognormally distributed. For example, it is useful to estimate annual load of a particular constituent at selected points along a stream in order to quantitatively determine sources or sinks of the particular constituent. If all the water passing a point on the stream were collected for a full year, the overall concentration of that constituent in the water multiplied by its total volume would give the desired load. If the total water volume were collected in small-sample volumes, the average load could be estimated from the arithmetic mean of the loads computed from each small-sample volume. In practice, only a few small-sample volumes are collected during the year, and the ratio of total water in the samples collected to total water passing a particular point along the stream may be less than 1 to 1 trillion. Because of this ratio and the underlying lognormal distribution, the arithmetic mean of the few samples is very sensitive to occasional large loads, and it can be shown (Sichel, 1952) that the arithmetic mean estimated from the few samples generally is greater than the true arithmetic mean of the total water volume.

A better estimate of the arithmetic mean of a censored lognormal distribution can be made using Sichel's " $t$ " estimator (Sichel, 1952) in conjunction with estimates of geometric mean and standard deviation described earlier in this section. The " $t$ " estimator based on Fisher's "Method of Maximum Likelihood" (Fisher, 1921) is an estimate of the arithmetic mean of the total water volume and may be computed from the following power series (Sichel, 1952):

$$
t=e^{\bar{X}}\left[1+1 / 2 V+\frac{n-1}{2^{2} 2 !(n+1)} v^{2}+\frac{(n-1)^{2}}{2^{3} 3 !(n+1)(n+3)} V^{3}+\ldots\right],
$$

where $\bar{X}=$ mean of the logarithms (base e),

$\mathrm{V}=$ variance of the logarithms or square of the standard deviation of the logarithms (base e), and

$\mathbf{n}=$ the total number of samples including those with concentrations less than detection limits.

NOTE: $\overline{\mathrm{X}}($ base e $)=2.3026 \overline{\mathrm{X}}$ (base 10), and

$$
\mathrm{V}(\text { base e })=(2.3026)^{2} \mathrm{~V} \text { (base 10). }
$$

The equations above were used to estimate average phosphorus loads presented in section 3.1, which are again presented in table 5.3-1 for the reader's convenience. 
Table 5.3-1 Average total phosphorus loads, 1974-78 water years.

[L Mean=Mean of logarithms (Base 10); L $\overline{\mathrm{S}} \mathrm{D}=\mathrm{Standard}$ deviation of logarithms; Avvg_Load=Average load, in tons per day]

\begin{tabular}{llcc}
\hline Station & L_Mean & L_SD & Avg_Load \\
\hline 09188500 & -1.981486 & 0.651740 & 0.031 \\
09205000 & -1.838354 & .707267 & .053 \\
09209400 & -1.612998 & .882251 & .180 \\
09211200 & -1.603068 & .551888 & .055 \\
09214500 & -2.946421 & 1.156198 & .027 \\
09216000 & -2.794096 & .802085 & .008 \\
09216050 & -2.270304 & .821662 & .030 \\
09216300 & -1.641843 & .742699 & .095 \\
09217000 & -1.013692 & .627777 & .269 \\
09217010 & -.694740 & .572333 & .473 \\
09222300 & -2.906847 & .607950 & .003 \\
09222400 & -2.360567 & 1.170525 & .121 \\
09224050 & -1.612482 & .413497 & .038 \\
09224450 & -2.523287 & 1.188375 & .107 \\
09234500 & -1.253458 & .556600 & .125 \\
\hline 0 & & & \\
\hline
\end{tabular}




\subsection{LOCATION OF WATER-QUALITY MEASUREMENT SITES}

\section{Water-quality measurement sites summarized in this report are referred to in three groups: routine surface-water sampling stations, miscellaneous surface-water sampling sites, and springs.}

Routine surface-water sampling stations are part of a nationwide water-quality monitoring network operated by the U.S. Geological Survey in cooperation with other Federal and State agencies. Each routine surface-water sampling station in this report has a unique number. The complete 8-digit number, such as 09188500 , includes the first two digits "09" that refer to the major drainage basin, and the remaining six digits " 188500 " that refer to individual station location. Increasing location numbers refer to locations progressively farther downstream.

Miscellaneous surface-water sites and springs represent a general reconnaissance and are not part of a routine measurement network. Data analyzed in this report are available from computer storage (U.S. Geological Survey, 1974) and may be found in publications such as Water Resources Data for Wyoming (U.S. Geological Survey, 1976; 1977). The location of each routine surface-water sampling station is shown in figure 6.0-1; the stations are described in table 6.0-1. The location of each of the more than 500 spring and miscellaneous surface-water sites for which data were analyzed in this report but not referred to individually is available through the data sources mentioned above.

Table 6.0-1 Description of routine surface-water sampling stations.

\begin{tabular}{|c|c|c|c|}
\hline $\begin{array}{l}\text { Station } \\
\text { number }\end{array}$ & Latitude & Long i tude & Location \\
\hline 09188500 & 430108 & 1100703 & $\begin{array}{l}\text { Green River at Warren Bridge, near Daniel, } \\
\text { Wyoming }\end{array}$ \\
\hline 09205000 & 423402 & 1095546 & New Fork River near Big Piney, Wyoming \\
\hline 09209400 & 421134 & 1100945 & Green River near LaBarge, Wyoming \\
\hline 09211200 & 420116 & 1100257 & $\begin{array}{l}\text { Green River below Fontenelle Reservoir, } \\
\text { Wyoming }\end{array}$ \\
\hline 09214500 & 421412 & 1091844 & Little Sandy Creek above Eden, Wyoming \\
\hline 09216000 & 420037 & 1093457 & Big Sandy River below Eden, Wyoming \\
\hline 09216050 & 415643 & 1094104 & $\begin{array}{l}\text { Big Sandy River at Gasson Bridge, near } \\
\text { Eden, Wyoming }\end{array}$ \\
\hline 09216300 & 414552 & 1094405 & $\begin{array}{l}\text { Green River at } \mathrm{Big} \text { Is land, near Green } \\
\text { River, Wyoming }\end{array}$ \\
\hline 09216527 & 413938 & 1073328 & Separation Creek, near Riner, Wyomfng \\
\hline 09216545 & 412935 & 1083047 & Bitter Creek near Bitter Creek, Wyoming \\
\hline 09216562 & 413852 & 1085950 & $\begin{array}{l}\text { Bitter Creek above Salt Wells Creek, near } \\
\text { Salt Wells, Wyoming }\end{array}$ \\
\hline 09216565 & 411156 & 1085952 & Salt Wells Creek near South Baxter, Wyoming \\
\hline 09216576 & 411225 & 1090309 & $\begin{array}{l}\text { Gap Creek below Bean Springs Creek, near } \\
\text { South Baxter, Wyoming }\end{array}$ \\
\hline 09216750 & 413750 & 1085918 & Salt Wells Creek near Salt We1ls, Wyoming \\
\hline 09216810 & 413556 & 1091354 & Kil lpecker Creek at Rock Springs, Wyoming \\
\hline 09216880 & 413300 & 1091815 & $\begin{array}{l}\text { Bitter Creek below Little Bitter Creek, } \\
\text { near Kanda, Wyoming }\end{array}$ \\
\hline 09217000 & 413059 & 1092654 & Green River near Green River, Wyoming \\
\hline 09217010 & 412946 & 1092617 & Green River below Green River, Wyoming \\
\hline 09222000 & 412708 & 1101020 & Blacks Fork near Lyman, Wyoming \\
\hline 09222300 & 413454 & 1103342 & Little Muddy Creek near Glencoe, Wyoming \\
\hline 09222400 & 413217 & 1101343 & Muddy Creek near Hampton, Wyomin \\
\hline 09224050 & 414506 & 1103157 & Hams Fork near Diamondville, Wyoming \\
\hline 09224450 & 413556 & 1095928 & Hams Fork near Granger, Wyoming \\
\hline ט9224700 & 413246 & 1094134 & Blacks Fork near Little America, Wyoming \\
\hline 09229500 & 410045 & 1094020 & Henrys Fork near Manila, Utah \\
\hline 09234500 & 405430 & 1092520 & Green River near Greendale, Utah \\
\hline 09235300 & 410054 & 1083839 & Vermillion Creek near Hiawatha, Colorado \\
\hline 09257000 & 410142 & 1073255 & Little Snake River near Dixon, Wyoming \\
\hline
\end{tabular}


EXPLANATION

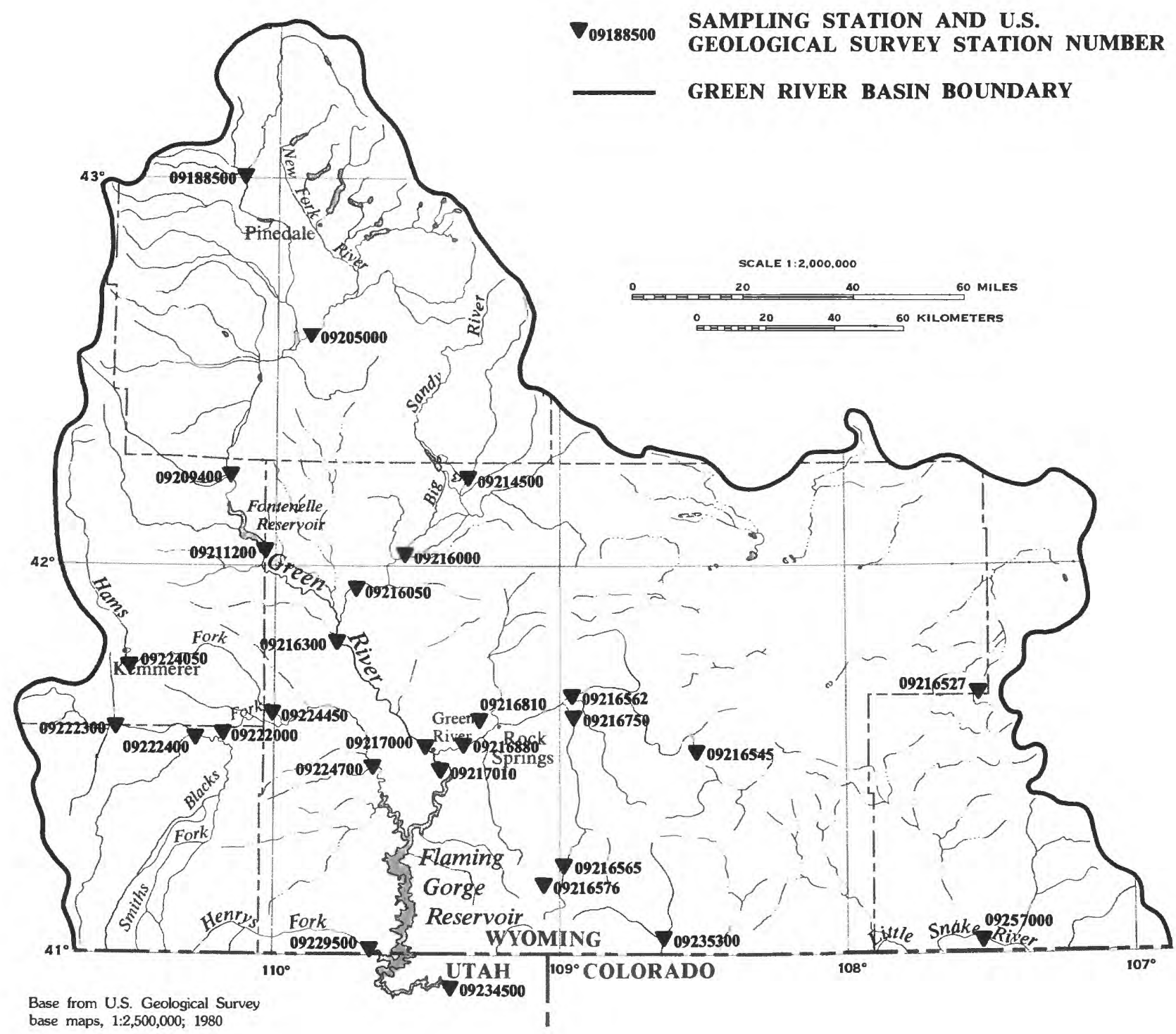

Figure 6.0-1 Location of routine surface-water sampling stations. 
Alekin, O. A., and Moricheva, N. P., 1957, The problem of the stability of the carbonate system in natural water: Akademiya Nauk SSSR Doklady [Geochem. Sec.], v. 117, p. 1030.

Barr, A. J., Goodnight, J. H., Sall, J. P., and Helwig, J. T., 1976, A user's guide to SAS 76: Raleigh, N.C., SAS Institute, Inc., 329 p.

Blom, G. 1958, Statistical estimates and transformed beta variables: New York, John Wiley, 462 p.

Bolke, E. L., 1979, Dissolved-oxygen depletion and other effects of storing water in Flaming Gorge Reservoir, Wyoming and Utah: U.S. Geological Survey Water-Supply Paper 2058, 41 p.

Bowker, A. H., and Lieberman, G. J., 1972, Engineering Statistics ( $2 \mathrm{~d}$ ed.): Englewood Cliffs, N.J., Prentice-Hall, p. 453-454.

CH2M Hill, Inc., 1977, Clean water report for southwestern Wyoming: Technical report prepared for the Southwestern Wyoming Water Quality Planning Association by $\mathrm{CH} 2 \mathrm{M}$ Hill, Inc., Denver, Colo., 224 p.

Cohen, A. C., Jr., 1959, Simplified estimators for the normal distribution when samples are singly censored or truncated: Technometrics, v. 1, no. 3, p. 217-237.

DeLong, L. L., 1977, An analysis of salinity in streams of the Green River Basin, Wyoming: U.S. Geological Survey Water-Resources Investigations 77-103, $32 \mathrm{p}$.

1978, Predicting effects of coal development on surface-water salinity, Green River Basin, Wyoming [abstract]: Protection of the Hydrologic Environment of Surface Mined Lands (Symposium), American Geophysical Union meeting, San Francisco, Calif., Dec, 1978, p. 1067.

Fisher, R. A., 1921, On the mathematical foundation of theoretical statistics, in Royal Society of London, Philosophical Transactions: London, ser. A, v. 222, p. 309-368.

Hem, J. D., 1961, Calculation and use of ion activity: U.S. Geological Survey Water-Supply Paper $1535 \mathrm{C}, 17 \mathrm{p}$.

1966, Chemical controls of irrigation drainage water composition: American Water Resources Conference, 2d, Chicago, Illinois, 1966, Proceedings, p. 64-77.

1970 , Study and interpretation of the chemical characteristics of natural water: U.S. Geological Survey Water-Supply Paper 1473, $363 \mathrm{p}$.

Jennings, M. E., and Benson, M. A., 1969, Frequency curves for annual flood series with some zero events or incomplete data: Water Resources Research, v. 5, no. 1, p. 276-280.

Landwehr, J. M., 1978, Some properties of the geometric mean and its use in water quality standards: Water Resources Research, v. 14, no. 2, p. 467-473.

Lowham, H. W., DeLong, L. L., Collier, K. R., and Zimmerman, E. A., 1982, Hydrology of Salt Wells Creek--A plains stream in southwestern Wyoming: U.S. Geological Survey WaterResources Investigations 81-62, $52 \mathrm{p}$.

Lowham, H. W., DeLong, L. L., Peter, K. D., Wangsness, D. J., Head, W. J., and Ringen, B. H., 1976, A plan for the study of water and its relation to economic development in the Green River and Great Divide Basins in Wyoming: U.S. Geological Survey Open-File Report 76-349, $92 \mathrm{p}$.

Miesch, A. T., 1967, Methods of computation for estimating geochemical abundance: U.S. Geological Survey Professional Paper 574-B, 15 p. 1976, Geochemical survey of Missouri, methods of sampling, laboratory analysis, and statistical reduction of data: U.S. Geological Survey Professional Paper 954-A, 39 p.

Riffenburg, H. B., 1925, Chemical character of ground water of the Northern Great Plains: U.S. Geological Survey Water-Supply Paper 560-B, p. 31-52.

Sichel, H. S., 1952, New methods in the statistical evaluation of mine sampling data: London, Institute of Mining and Metallurgy Transactions, v. 61, p. 261-288.

Skougstad, M. W., Fishman, M. J., Friedman, L. C., Erdman, D. E., and Duncan, S. S., 1979, Methods for determination of inorganic substances in water and fluvial sediments: U.S. Geological Survey Techniques of WaterResources Investigations, Book 5, Chapter A1, $626 \mathrm{p}$.

U.S. Environmental Protection Agency, 1977, Report on Flaming Gorge Reservoir, Sweetwater County, Wyoming, and Daggett County, Utah, EPA Region VIII: U.S. Environmental Protection Agency, National Eutrophication Survey Working Paper No. 885, 63 p.

U.S. Geological Survey, 1974, WATSTORE - U.S. Geological Survey National Water Data Storage and Retrieval System: U.S. Geological Survey INF-74-23, 15 p.

1976, Water resources data for Wyoming, Water Year 1976, Volume 2, Green River, Bear River, and Snake River Basins: U.S. Geological Survey Water-Data Report WY 76-2, 436 p. 
1977, Water resources data for Wyoming, Water Year 1977, Volume 2, Green River, Bear River, and Snake River Basins: U.S. Geological Survey Water-Data Report WY 77-2, 484 p.

Welder, G. E., 1968, Ground-water reconnaissance of the Green River Basin, southwestern Wyoming: U.S. Geological Survey Hydrologic Investigations Atlas HA-290.

Welder, G. E., and McGreevy, L. J., 1966, Ground- water reconnaissance of the Great Divide and Washakie Basins and some adjacent areas, southwestern Wyoming: U.S. Geological Survey Hydrologic Investigations Atlas HA-219.

Wyoming Water Planning Program, 1970, Water and related land resources of the Green River Basin, Wyoming: Wyoming State Engineer's Office, Report No. 3 and addendum, 167 p. 


\subsection{STATISTICAL SUMMARY OF TRACE-ELEMENT CONCENTRATIONS AT ROUTINE SURFACE-WATER SAMPLING STATIONS}

8.0 STATISTICAL SUMMARY OF TRACE-ELEMENTS CONCENTRATIONS

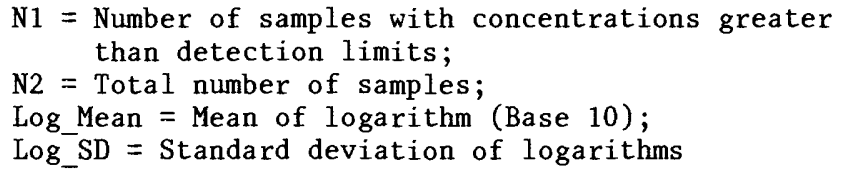

ARSENIC

\begin{tabular}{|c|c|c|c|c|c|c|c|c|}
\hline \multirow{2}{*}{$\begin{array}{l}\text { Site or } \\
\text { Station }\end{array}$} & \multicolumn{4}{|c|}{ Dissolved } & \multicolumn{4}{|c|}{ Total } \\
\hline & N1 & $\overline{\mathrm{N} 2}$ & Log Mean & $\log$ SD & N1 & $\mathrm{N} 2$ & Log Mean & Log SD \\
\hline Misc-SW & 20 & 28 & 0.129831 & 0.298508 & 20 & 22 & 0.820537 & 0.718648 \\
\hline Springs & 9 & 18 & .011747 & .539464 & 31 & 43 & -.018871 & 1.052088 \\
\hline 09209400 & - & - & ------ & $\ldots-.--$ & 10 & 13 & -.047066 & .399289 \\
\hline 09211200 & - & - & ------ & 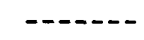 & 11 & 12 & .024868 & .200920 \\
\hline 09214500 & - & - & ----- & $--\cdots--$ & 1 & 3 & ----- & ----- \\
\hline 09216000 & 12 & 12 & .280207 & .319742 & 13 & 13 & .418590 & .490640 \\
\hline 09216527 & - & - & ----- & ------ & 5 & 5 & .654461 & .627264 \\
\hline 09216545 & 4 & 4 & .150515 & .193351 & 15 & 15 & .552681 & .378719 \\
\hline 09216562 & - & - & ------ & ----- & 9 & 10 & .309929 & .547071 \\
\hline 09216565 & - & - & ----- & ----- & 11 & 11 & .455642 & .483767 \\
\hline 09216576 & 4 & 4 & .119280 & .341083 & 5 & 5 & .388897 & .441358 \\
\hline 09216750 & - & - & ----- & ----- & 8 & 8 & 1.357502 & .505310 \\
\hline 09216810 & 10 & 12 & .081779 & .359547 & 12 & 12 & .569967 & .227697 \\
\hline 09216880 & 12 & 12 & .917538 & .466349 & 12 & 12 & 1.068463 & .502949 \\
\hline 09217000 & 9 & 13 & -.045118 & .235257 & 11 & 13 & .023935 & .225697 \\
\hline 09217010 & 10 & 13 & .036004 & .276979 & 10 & 12 & .162171 & .240669 \\
\hline $092185^{\circ} 00$ & - & - & ----- & ----- & 1 & 2 & ----- & ------ \\
\hline 09222300 & 4 & 5 & .068841 & .276916 & 12 & 14 & .176440 & .296950 \\
\hline 09222400 & 5 & 5 & .311261 & .436568 & 16 & 16 & .449214 & .353226 \\
\hline 09224050 & 11 & 12 & .092761 & .220079 & 11 & 12 & .171454 & .274278 \\
\hline 09235300 & 5 & 5 & .060206 & .204129 & 13 & 13 & .743762 & .889410 \\
\hline 09257000 & 5 & 5 & 180618 & 215411 & 4 & 4 & .225772 & .215199 \\
\hline
\end{tabular}

BARIUM

\begin{tabular}{lrrrrrrrrr}
\hline Site or & \multicolumn{4}{c}{ Dissolved } & \multicolumn{5}{c}{ Total } \\
\cline { 2 - 6 } Station & N1 & N2 & Log Mean & Log SD & N1 & N2 & Log Mean & Log SD \\
\hline Misc-SW & 12 & 20 & 1.938395 & 0.262092 & 16 & 17 & 2.436076 & 0.761356 \\
Springs & 5 & 13 & .983534 & 1.200210 & 39 & 43 & 2.290691 & .750487
\end{tabular}

BORON

\begin{tabular}{|c|c|c|c|c|c|c|c|c|}
\hline \multirow{2}{*}{$\begin{array}{l}\text { Site or } \\
\text { Station }\end{array}$} & \multicolumn{4}{|c|}{ Dissolved } & \multicolumn{4}{|c|}{ Total } \\
\hline & N1 & $\mathrm{N} 2$ & Log Mean & Log SD & N1 & N2 & Log Mean & Log SD \\
\hline Misc-SW & 32 & 32 & 1.770796 & 0.624186 & & & & \\
\hline Springs & 55 & 56 & 2.014201 & .700003 & 6 & 7 & 1.311696 & 0.340256 \\
\hline 09188500 & 3 & 3 & 1.359727 & .135025 & 12 & 12 & 1.890589 & .278190 \\
\hline 09211200 & - & - & $-\ldots$ & $-\cdots-\cdots$ & 11 & 11 & 1.803293 & .196321 \\
\hline 09216000 & - & - & ----- & ------ & 12 & 12 & 2.538700 & .132279 \\
\hline 09216527 & 5 & 5 & 2.012591 & .259358 & - & - & ----- & ----- \\
\hline 09216545 & 15 & 15 & 2.337002 & .095846 & - & - & - & \\
\hline 09216562 & 10 & 10 & 2.682833 & .242573 & - & - & --- & \\
\hline 09216565 & 12 & 12 & 2.161539 & .132544 & - & - & & \\
\hline 09216576 & 6 & 6 & 2.067107 & .147130 & - & - & & \\
\hline 09216750 & 8 & 8 & 2.781742 & .118190 & - & - & -- & \\
\hline 09216810 & 12 & 12 & 3.272463 & .288056 & - & - & & \\
\hline 09216880 & 12 & 12 & 2.651740 & .542541 & - & - & & \\
\hline 09217000 & 13 & 14 & 1.763570 & .173855 & - & - & ----- & $-\ldots-\ldots$ \\
\hline 09217010 & 12 & 13 & 1.817728 & .176067 & - & - & 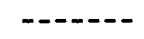 & $----\infty$ \\
\hline 09222300 & 14 & 14 & 3.231787 & .368344 & - & - & ---- & ------ \\
\hline 09222400 & 16 & 16 & 3.091807 & .375553 & - & - & ----- & $--\cdots+-$ \\
\hline 09224050 & 12 & 12 & 1.689086 & .161156 & - & - & $-\cdots---$ & $---m$ \\
\hline 09235300 & 14 & .14 & 2.208319 & .093588 & - & - & $---1-$ & ------ \\
\hline
\end{tabular}


CADMIUM

\begin{tabular}{|c|c|c|c|c|c|c|c|c|}
\hline Site or & & & Dissolved & & & & Total & \\
\hline Station & $\mathrm{N} 1$ & $\mathrm{~N} 2$ & Log Mean & Log SD & $\mathrm{N} 1$ & $\mathrm{~N} 2$ & Log Mean & Log SD \\
\hline Misc-SW & 10 & 30 & -0.795112 & 1.060640 & 15 & 29 & 0.491781 & 0.452993 \\
\hline Springs & 4 & 21 & -.500116 & .423996 & 21 & 54 & .093764 & .703853 \\
\hline 09209400 & 10 & 12 & .066096 & .342347 & 6 & 13 & .772779 & .625052 \\
\hline 09211200 & 8 & 12 & .123962 & .507693 & 4 & 12 & .975346 & .199190 \\
\hline 09213810 & - & - & ---- & $-----\infty$ & 10 & 11 & 993019 & .442685 \\
\hline 09214500 & 3 & 3 & .318081 & .365852 & 2 & 3 & & \\
\hline 09216000 & 11 & 12 & .263827 & .291957 & 10 & 13 & .863976 & .387338 \\
\hline 09216527 & 1 & 3 & 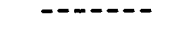 & ----.-- & 2 & 5 & $-\cdots--$ & $---\cdot-$ \\
\hline 09216545 & - & - & $--1-1$ & ----- & 8 & 15 & .749743 & .480722 \\
\hline 09216562 & 4 & 4 & .313818 & .263536 & 9 & 12 & .846733 & .427020 \\
\hline 09216565 & 3 & 6 & -.234757 & .555482 & 7 & 11 & .830627 & .320409 \\
\hline 09216576 & 3 & 4 & .092551 & .309216 & 1 & 5 & - - & 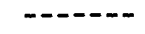 \\
\hline 09216750 & - & - & ----- & ------ & 7 & 8 & .676736 & .603059 \\
\hline 09216810 & 10 & 12 & .268225 & .346760 & - & - & $-\infty-1-4$ & $-\cdots--$ \\
\hline 09216880 & 12 & 12 & .125429 & .169609 & 9 & 12 & .777981 & .485836 \\
\hline 09217000 & 10 & 13 & .070180 & .413639 & 6 & 13 & .772779 & .625052 \\
\hline 09217010 & 10 & 13 & .085375 & .505554 & 5 & 13 & .722970 & .581831 \\
\hline 09218500 & 1 & 2 & ---N- & --1-- & - & - & 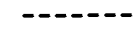 & $--1-0$ \\
\hline 09222000 & 1 & 2 & ------ & ---- & - & - & ------ & ----- \\
\hline 09222300 & 5 & 5 & .120412 & .215411 & 9 & 14 & .783303 & .304374 \\
\hline 09222400 & 3 & 5 & -.160737 & .646569 & 7 & 16 & .735464 & .572777 \\
\hline 09224050 & 9 & 12 & -.035486 & . 309981 & 4 & 12 & .739703 & .543437 \\
\hline 09224700 & 1 & 2 & - - & $-\ldots--$ & - & - & -...- & $-\ldots-$. \\
\hline 09235300 & 4 & 5 & .357354 & .213456 & 9 & 13 & .775982 & .668251 \\
\hline 09257000 & 2 & 7 & ------- & ------ & 2 & 7 & $---n--$ & $---\cdots$ \\
\hline
\end{tabular}

CHROMIUM

\begin{tabular}{|c|c|c|c|c|c|c|c|c|}
\hline Site or & & & Dissolved & & & & Total & \\
\hline Station & N1 & $\mathrm{N} 2$ & Log Mean & $\log \mathrm{SD}$ & $\overline{\mathrm{N}} 1$ & $\mathrm{~N} 2$ & Log Mean & $\log S D$ \\
\hline lisc-SW & 17 & 28 & 0.746585 & 0.354923 & 17 & 23 & 1.238870 & 0.723039 \\
\hline Springs & 5 & 20 & .999999 & .000001 & 36 & 49 & .508931 & .431486 \\
\hline 09188500 & 1 & 2 & ------ & ------ & - & - & ------ & ------ \\
\hline 09209400 & 1 & 12 & $----n$ & $---\cdots$ & 5 & 13 & .664901 & .632350 \\
\hline 09211200 & 3 & 12 & $----0-0$ & $----n$ & 3 & 12 & ----- & $--\ldots$ \\
\hline 09214500 & 1 & 3 & $--1-$ & ----- & - & - & ------ & $-\ldots-$ \\
\hline 09216000 & 2 & 12 & $\ldots$ & 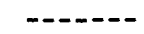 & 5 & 13 & .881846 & .561556 \\
\hline 09216527 & - & - & ---- & ---- & 4 & 5 & 1.324008 & .326512 \\
\hline 09216545 & 1 & 4 & ----- & - & 9 & 15 & .874015 & .639644 \\
\hline 09216562 & 2 & 4 & - & ------ & 7 & 10 & .965461 & .263489 \\
\hline 09216565 & - & - & - & $-\infty---$ & 5 & 11 & .891405 & .448951 \\
\hline 09216576 & 1 & 4 & $---\infty-$ & $-\ldots$ & 1 & 5 & ---- & $-\cdots+-$ \\
\hline 09216750 & 1 & 2 & 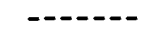 & 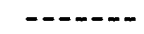 & 8 & 8 & 1.563576 & .338769 \\
\hline 09216810 & 7 & 12 & 1.000000 & .342960 & 11 & 12 & 1.133528 & .206338 \\
\hline 09216880 & 5 & 12 & .781080 & .318005 & 7 & 12 & .961010 & .485396 \\
\hline 09217000 & 2 & 12 & 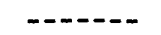 & $\ldots$ & 5 & 12 & $\ldots$ & $\ldots$ \\
\hline 09217010 & 1 & 13 & 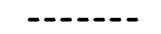 & ------ & 6 & 13 & .688890 & .445714 \\
\hline 09222000 & 1 & 2 & $-\cdots-1$ & - & 6 & 14 & .792121 & .298034 \\
\hline 09222400 & 1 & 5 & $\ldots$ & $--\infty-\infty$ & 9 & 16 & .940825 & .435381 \\
\hline 09224050 & 3 & 12 & - & ----- & 5 & 12 & .781080 & .318005 \\
\hline 09224450 & 1 & 2 & 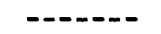 & - & - & - & -+- & $--1-$ \\
\hline 09224700 & 1 & 2 & $\ldots$ & $-\ldots$ & 1 & 2 & $--1-$ & ------ \\
\hline 09235300 & 2 & 5 & $-\ldots-1$ & $-\ldots$ & 8 & 13 & .928160 & .827881 \\
\hline
\end{tabular}


8.0 STATISTICAL SUMMARY OF TRACE ELEMENTS--CONTINUED

COPPER

\begin{tabular}{|c|c|c|c|c|c|c|c|c|}
\hline \multirow{2}{*}{$\begin{array}{l}\text { Site or } \\
\text { Station }\end{array}$} & \multicolumn{4}{|c|}{ Dissolved } & \multicolumn{4}{|c|}{ Total } \\
\hline & $\overline{\mathrm{N}} \mathrm{l}$ & N2 & Log Mean & Log SD & $\overline{\mathrm{N} 1}$ & $\mathrm{~N} 2$ & Log Mean & Log SD \\
\hline isc-SW & 14 & 30 & -0.196227 & 0.724915 & 27 & 29 & 1.265916 & 0.604515 \\
\hline Springs & 12 & 12 & .006371 & .511108 & 46 & 55 & .392030 & .555859 \\
\hline 09188500 & 1 & 2 & ----0 &.----0 & - & - & ------ & --- \\
\hline 09205000 & 1 & 2 & $-\ldots$ & $-\ldots$ & - & - &.---1 & -- \\
\hline 09209400 & 11 & 12 & .256785 & .328950 & 6 & 13 & 1.153448 & .612506 \\
\hline 09211200 & 8 & 12 & .256399 & .321647 & 5 & 12 & 1.030615 & .559687 \\
\hline 09214500 & 3 & 3 & .518767 & .274389 & 2 & 3 & $\ldots$ & 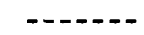 \\
\hline 09216000 & 12 & 12 & .486634 & .334626 & 11 & 13 & 1.128196 & .331904 \\
\hline 09216527 & 3 & 3 & .359727 & .346241 & 5 & 5 & 1.288181 & .413175 \\
\hline 09216545 & 4 & 4 & .526802 & .303186 & 13 & 15 & 1.128270 & .231736 \\
\hline 09216562 & 4 & 4 & .495568 & .168245 & 10 & 10 & 1.132222 & .328266 \\
\hline 09216565 & 4 & 6 & .011131 & .384125 & 8 & 11 & 1.111833 & .281811 \\
\hline 09216576 & 3 & 4 & .000000 & .454777 & 4 & 5 & ---- & $---n$ \\
\hline 09216750 & 2 & 2 & 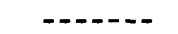 & - & 8 & 8 & 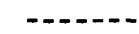 & $-\ldots-n$ \\
\hline 09216810 & 12 & 12 & .526394 & .355560 & 11 & 12 & 1.160326 & .338300 \\
\hline 09216880 & 12 & 12 & .465810 & .333080 & 10 & 12 & 1.229205 & .279016 \\
\hline 09217000 & 9 & 12 & .187153 & .501330 & 9 & 13 & 1.195193 & .645858 \\
\hline 09217010 & 11 & 13 & .145221 & .389794 & 8 & 13 & .914087 & .201174 \\
\hline 09218500 & 1 & 2 & 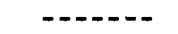 & 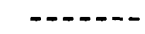 & 2 & 2 & - & 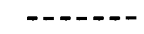 \\
\hline 09222000 & 1 & 2 & 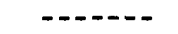 & 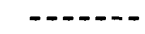 & 1 & 1 & ----- & ---- \\
\hline 09222300 & 5 & 5 & .571466 & .281104 & 11 & 14 & 1.063983 & .322018 \\
\hline 09222400 & 4 & 5 & .313309 & .594195 & 14 & 16 & 1.089621 & .295527 \\
\hline 09224050 & 6 & 12 & -.009318 & .507931 & 7 & 12 & .922058 & .183940 \\
\hline 09224450 & 2 & 2 & 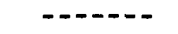 & - & - & - & - - & 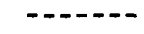 \\
\hline 09224700 & 1 & 2 & $--1-4$ & - & 2 & 2 & - & \\
\hline 09235300 & 4 & 5 & .586468 & .178366 & 10 & 13 & 1.135870 & .326827 \\
\hline 09257000 & 5 & 7 & .003865 & .357468 & 3 & 7 & --- & \\
\hline
\end{tabular}

IRON

\begin{tabular}{|c|c|c|c|c|c|c|c|c|}
\hline Site or & & & Dissolved & & & & Total & \\
\hline Station & N1 & $\mathrm{N} 2$ & Log Mean & Log SD & N1 & N2 & Log Mean & $\overline{\log S D}$ \\
\hline Misc-SW & 45 & 46 & 1.765056 & 0.339468 & - & - & $--1-0$ & 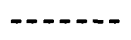 \\
\hline Springs & 61 & 64 & 1.780503 & .937305 & - & - & & 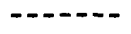 \\
\hline 09209400 & 11 & 12 & 1.400799 & .294776 & - & - & $----n$ & 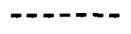 \\
\hline 09211200 & 11 & 12 & 1.320100 & .330483 & - & - & ----- & 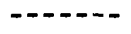 \\
\hline 09216000 & 11 & 12 & 1.297491 & . 398695 & - & - & 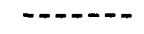 & $--1-2$ \\
\hline 09216527 & 5 & 5 & 2.016298 & .533520 & - & - & $-\cdots$ & $--n$ \\
\hline 09216545 & 14 & 15 & 1.837800 & .478823 & - & - & $--n--$ & $-\ldots$ \\
\hline 09216565 & 12 & 12 & 1.872401 & .434491 & - & - & -----4 & 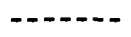 \\
\hline 09216576 & 6 & 6 & 1.790166 & .759865 & - & - & ----- & $-\ldots$ \\
\hline 09216750 & 8 & 8 & 1.655812 & .440449 & - & - & -- & $-\cdots-$ \\
\hline 09216810 & 11 & 12 & 1.901847 & .485277 & - & - & -- & $-\ldots$ \\
\hline 09216880 & 12 & 12 & 1.837550 & .333920 & - & - & -- & - \\
\hline 09217000 & 11 & 12 & 1.330325 & .493496 & - & - & -. & 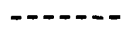 \\
\hline 09217010 & 10 & 13 & 1.314672 & .292042 & - & - & -- & $-\cdots$ \\
\hline 09222300 & 13 & 14 & 1.763910 & .403631 & - & - & 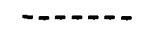 & ----2 \\
\hline 09222400 & 16 & 16 & 1.815513 & .486836 & - & - & $---n$ & $----n$ \\
\hline 09224050 & 12 & 12 & 1.635262 & .362127 & - & - & 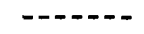 & -----0 \\
\hline 09235300 & 14 & 14 & 1.869206 & .595897 & - & - & 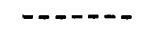 & ----4 \\
\hline 09257000 & 7 & 7 & 1.773376 & .259552 & - & - & ------ & ------- \\
\hline 09276562 & 10 & 10 & 1.676582 & .372749 & - & - & ------ & ------- \\
\hline
\end{tabular}


8.0 STATISTICAL SUMMARY OF TRACE ELEMENTS--CONTINUED

LEAD

\begin{tabular}{|c|c|c|c|c|c|c|c|c|}
\hline Site or & & & Dissolved & & & & Total & \\
\hline Station & N1 & N2 & Log Mean & $\log$ SD & N1 & N2 & Log Mean & $\log$ SD \\
\hline Misc-SW & 18 & 30 & 0.000112 & 0.920091 & 18 & 29 & 1.535608 & 0.511762 \\
\hline Springs & 11 & 21 & -.222502 & .696572 & 32 & 55 & .760753 & .910449 \\
\hline 09188500 & 1 & 2 & ---- & $--1--$ & - & - & ----- & ----1 \\
\hline 09209400 & 7 & 12 & .165097 & .474368 & 6 & 13 & 1.873261 & .348653 \\
\hline 09211200 & 9 & 12 & .179545 & .597228 & 1 & 12 & ---1 & 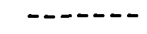 \\
\hline 09216000 & 9 & 12 & .333600 & .556084 & 7 & 13 & 1.799527 & .566849 \\
\hline 09216527 & 2 & 3 & $--1--$ & $--1--$ & 2 & 5 & ---1 & $-\ldots-1$ \\
\hline 09216545 & 3 & 4 & - & 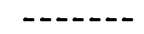 & 7 & 15 & 1.669501 & .435848 \\
\hline 09216562 & 4 & 4 & .508356 & .227389 & 8 & 10 & 1.549301 & .557620 \\
\hline 09216565 & 3 & 6 & .125100 & .659609 & 6 & 11 & 1.527325 & .625957 \\
\hline 09216576 & 3 & 4 & .271389 & .658625 & 1 & 5 & ---- & 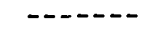 \\
\hline 09216750 & 2 & 2 & $--1-1$ & $--1-$ & 7 & 8 & 1.970058 & .295581 \\
\hline 09216810 & 12 & 12 & .610015 & .371272 & 9 & 12 & 1.792447 & .517318 \\
\hline 09216880 & 11 & 12 & .467953 & .298461 & 4 & 12 & 1.741503 & .628700 \\
\hline 09217000 & 9 & 13 & .168593 & .612174 & 1 & 12 & 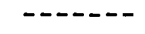 & $\ldots-\ldots$ \\
\hline 09217010 & 12 & 13 & .477245 & .605951 & 2 & 13 & 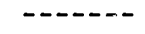 & --- \\
\hline 09218500 & 1 & 2 & $--1--$ & $--1--$ & - & - & 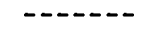 & $-\ldots$ \\
\hline 09222000 & 1 & 2 & $--2-2$ & ------ & - & - & - - & ------ \\
\hline 09222300 & 3 & 5 & $---1-$ & $--1-$ & 9 & 14 & 1.589685 & .571406 \\
\hline 09222400 & 4 & 5 & .413372 & .746369 & 7 & 16 & 1.665209 & .539228 \\
\hline 09224050 & - & - & ---- & ----- & 5 & 12 & ---1 & ---1 \\
\hline 09224450 & 8 & 13 & .357533 & .275219 & - & - & ---- & 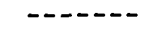 \\
\hline 09235300 & 4 & 5 & .260963 & .491114 & 6 & 13 & 1.820204 & .729260 \\
\hline 09257000 & 4 & 7 & .044845 & .535510 & 2 & 7 & & \\
\hline
\end{tabular}

MANGANESE

\begin{tabular}{|c|c|c|c|c|c|c|c|c|}
\hline \multirow{2}{*}{$\begin{array}{l}\text { Site or } \\
\text { Station }\end{array}$} & \multicolumn{4}{|c|}{ Dissolved } & \multicolumn{4}{|c|}{ Total } \\
\hline & N1 & N2 & Log Mean & $\log S D$ & N1 & $\mathrm{N} 2$ & Log Mean & Log SD \\
\hline Misc-SW & 28 & 31 & 1.076541 & 0.314760 & - & - & 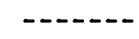 & $\cdots-$ \\
\hline Springs & 47 & 54 & 1.381461 & .965381 & - & - & ---- & ---- \\
\hline 09209400 & 8 & 12 & .886961 & .315082 & - & - & $\ldots$ & $\ldots$ \\
\hline 09211200 & 8 & 12 & .890813 & .431432 & - & - & $-\ldots$ & $\ldots$ \\
\hline 09216000 & 11 & 12 & 1.148731 & .260186 & - & - & $\ldots$ & $\ldots$ \\
\hline 09216527 & 3 & 3 & 1.382042 & .486011 & - & - & 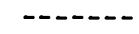 & ---1 \\
\hline 09216545 & 4 & 4 & 1.150515 & .286933 & - & - & --- & ---- \\
\hline 09216562 & 4 & 4 & 2.416439 & .105102 & - & - & $\ldots$ & $\ldots$ \\
\hline 09216565 & 6 & 6 & 2.218251 & .408684 & - & - & - & - \\
\hline 09216576 & 4 & 4 & 2.064683 & .152227 & - & - & $\ldots$ & $\ldots$ \\
\hline 09216810 & 12 & 12 & 2.959255 & .599444 & - & - & -+-- & ------ \\
\hline 09216880 & 12 & 12 & 2.225580 & .232974 & - & - & $\ldots$ & 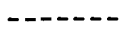 \\
\hline 09217000 & 9 & 12 & .822687 & .437793 & - & - & - & - \\
\hline 09217010 & 10 & 13 & .964853 & .409923 & - & - & $\ldots$ & $\ldots$ \\
\hline 09222300 & 5 & 5 & 1.476042 & .405551 & - & - & --- & ---- \\
\hline 09222400 & 5 & 5 & 1.180618 & .215411 & - & - & 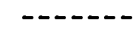 & --- \\
\hline 09224050 & 12 & 12 & 1.708687 & .386140 & - & - & ---- & ----1 \\
\hline 09235300 & 5 & 5 & 2.109506 & .241465 & - & - & ----1 & ---- \\
\hline 09257000 & 6 & 6 & 1.421057 & .320326 & - & - & $--1-$ & --- \\
\hline
\end{tabular}


MOLYBDENUM

\begin{tabular}{|c|c|c|c|c|c|c|c|c|}
\hline Site or & & & Dissolved & & & & Total & \\
\hline Station & N1 & $\mathrm{N} 2$ & Log Mean & $\log$ SD & N1 & N2 & Log Mean & Log SD \\
\hline Misc-SW & 17 & 28 & 0.186752 & 0.463614 & 22 & 23 & 0.542350 & 0.368419 \\
\hline Springs & 11 & 20 & .116621 & .856924 & 40 & 49 & .658481 & .528263 \\
\hline 09209400 & 8 & 12 & -.074683 & .337426 & 9 & 13 & .309024 & .339851 \\
\hline 09211200 & 10 & 12 & ----- & ----- & 8 & 12 & .050823 & .460341 \\
\hline 09216000 & 11 & 12 & .845351 & .159766 & 13 & 13 & .822063 & .182663 \\
\hline 09216527 & 1 & 3 & .989760 & .128127 & 5 & 5 & .396454 & .338472 \\
\hline 09216545 & - & - & ------ & 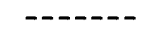 & 15 & 15 & .981920 & .124783 \\
\hline 09216562 & 4 & 4 & .837562 & 328619 & 10 & 10 & .668950 & .329222 \\
\hline 09216565 & 6 & 6 & .704218 & .108664 & 11 & 11 & .788009 & .174924 \\
\hline 09216576 & 4 & 4 & ------ & ----- & 5 & 5 & .580618 & .177187 \\
\hline 09216750 & 1 & 1 & ----- & -----1 & 7 & 8 & .719668 & .249777 \\
\hline 09216810 & 12 & 12 & .937133 & .194318 & 12 & 12 & .935540 & .231719 \\
\hline 09216880 & 11 & 12 & .364290 & .356283 & 12 & 12 & .618091 & .235470 \\
\hline 09217000 & 10 & 12 & .147227 & .330284 & 11 & 13 & .174865 & .357341 \\
\hline 09217010 & 11 & 13 & .191475 & .381034 & 13 & 13 & .335575 & .206833 \\
\hline 09222300 & 5 & 5 & 1. 168462 & .201923 & 14 & 14 & 1.143121 & .178839 \\
\hline 09222400 & 5 & 5 & 1.120231 & .090542 & 16 & 16 & .983419 & .274418 \\
\hline 09224050 & 3 & 12 & ----- & ------- & 8 & 12 & .095261 & .416334 \\
\hline 09235300 & 5 & 5 & .781310 & .123136 & 13 & 13 & .791704 & .118735 \\
\hline
\end{tabular}

NICKEL

\begin{tabular}{|c|c|c|c|c|c|c|c|c|}
\hline \multirow{2}{*}{$\begin{array}{l}\text { Site or } \\
\text { Station } \\
\end{array}$} & \multicolumn{4}{|c|}{ Dissolved } & \multicolumn{4}{|c|}{ Total } \\
\hline & $\mathrm{N} 1$ & N2 & Log Mean & $\log S D$ & $\mathrm{~N} 1$ & $\mathrm{~N} 2$ & Log Mean & Log SD \\
\hline Misc-SW & 7 & 8 & 0.398370 & 0.222160 & 4 & 7 & 1.776302 & 0.297087 \\
\hline Springs & 3 & 10 & -.368910 & 1.481439 & 2 & 14 & $---1-$ & ---- \\
\hline 09209400 & 10 & 12 & .292006 & .334505 & 3 & 13 & 1.378886 & .82737 \\
\hline 09211200 & 11 & 11 & .333047 & .224974 & 3 & 12 & --- & ----1 \\
\hline 09216000 & 8 & 12 & .168307 & .451319 & 7 & 13 & 1.512381 & .598411 \\
\hline 09216527 & 1 & 3 & -----1 & ------ & 3 & 5 & 1.395153 & .531671 \\
\hline 09216545 & 4 & 4 & .464333 & .143466 & 9 & 15 & 1.366830 & .391023 \\
\hline 09216562 & 4 & 4 & .838911 & .097542 & 7 & 10 & 1.396986 & .470240 \\
\hline 09216565 & 4 & 4 & ------ & 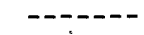 & 7 & 10 & 1.238846 & .558720 \\
\hline 09216576 & 3 & 3 & -----1 & $---1--$ & - & - & $---1-$ & ----- \\
\hline 09216750 & 1 & 2 & -----1 & ----1 & 7 & 8 & 1.835021 & .276580 \\
\hline 09216810 & 12 & 12 & 1.030229 & .202344 & 11 & 12 & 1.696427 & .376603 \\
\hline 09216880 & 12 & 12 & .717118 & .164120 & 3 & 12 & 1.468189 & .490272 \\
\hline 09217000 & 9 & 12 & .244374 & .397151 & 2 & 13 & ----- & ---- \\
\hline 09217010 & 11 & 13 & .361741 & .225273 & 2 & 13 & ------ & $----n$ \\
\hline 09222300 & 4 & 5 & .911930 & .089733 & 8 & 14 & 1.427589 & .337161 \\
\hline 09222400 & 4 & 4 & .778151 & .167845 & 8 & 15 & 1.398650 & .438420 \\
\hline 09224050 & 11 & 12 & .296336 & .278263 & 2 & 12 & ----- & \\
\hline 09235300 & 4 & 4 & .595053 & .105730 & 8 & 13 & 1.374996 & .486366 \\
\hline 09257000 & 3 & 5 & 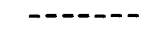 & ------ & 2 & 5 & & \\
\hline
\end{tabular}


8.0 STATISTICAL SUMMARY OF TRACE ELEMENTS--CONTINUED

VANADIUM

\begin{tabular}{|c|c|c|c|c|c|c|c|c|}
\hline Site or & & & Dissolved & & & & Total & \\
\hline Station & $\overline{\mathrm{N}} 1$ & N2 & Log Mean & Log SD & $\mathrm{N} 1$ & N2 & Log Mean & Log SD \\
\hline Misc-SW & 8 & 8 & 0.128514 & 0.398020 & - & - & ------ & -ー---- \\
\hline Springs & 6 & 10 & .126936 & 1. 163908 & - & - & ------- & ------- \\
\hline 09209400 & 7 & 11 & -.473593 & .542967 & - & - & ----1 & ------ \\
\hline 09211200 & 6 & 10 & -.275350 & .209085 & - & - & -ー-ー- & ----- \\
\hline 09216000 & 8 & 9 & .187322 & .264914 & - & - & ------ & ------ \\
\hline 09216562 & 4 & 4 & ----- & - - - & - & - & ------ & ---- \\
\hline 09216565 & 1 & 4 & ----- & - - & - & - & ------ & ------ \\
\hline 09216576 & 3 & 3 & ----- & ----- & - & - & ------ & ------ \\
\hline 09216750 & 1 & 2 & ----- & ---- & - & - & ------ & ----- \\
\hline 09216810 & 10 & 12 & .775107 & .365733 & - & - & ---- & ---- \\
\hline 09216880 & 11 & 12 & .458768 & .235883 & - & - & ---- & - - \\
\hline 09217000 & 9 & 12 & -.334517 & .292131 & - & - & - - & $--\therefore--$ \\
\hline 09217010 & 9 & 13 & -.294024 & .285565 & - & - & - - - & ------ \\
\hline 09222300 & 2 & 5 & ---- & ---- & - & - & ----- & ----- \\
\hline 09222400 & 3 & 4 & .103193 & .354257 & - & - & ---י- & ----- \\
\hline 09224050 & 7 & 12 & -.606321 & .557978 & - & - & - - & $-\cdots$ \\
\hline 09235300 & 1 & 4 & --- & ----- & - & - & ----- & - - - \\
\hline 09257000 & 4 & 5 & -.000422 & .472970 & - & - & ------ & ---- \\
\hline
\end{tabular}

ZINC

\begin{tabular}{|c|c|c|c|c|c|c|c|c|}
\hline Site or & & & Dissolved & & & & Total & \\
\hline Station & N1 & N2 & Log Mean & $\log$ SD & N1 & N2 & Log Mean & Log SD \\
\hline Misc-SW & 13 & 28 & 0.817970 & 0.256938 & 21 & 23 & 1.780899 & 0.832538 \\
\hline Springs & 13 & 20 & 1.031358 & 1.169338 & 37 & 49 & .946874 & .721753 \\
\hline 00921654 & 4 & 4 & 1.150515 & .193351 & - & - & $----n$ & ------ \\
\hline 09209400 & 8 & 12 & .725504 & .367199 & 12 & 13 & 1.269561 & .330986 \\
\hline 09211200 & 6 & 12 & .666381 & .402542 & 10 & 12 & 1.211982 & .297092 \\
\hline 09216000 & 10 & 12 & $-\ldots-n$ & ----- & 12 & 12 & 1.455238 & .368390 \\
\hline 09216527 & 2 & 3 & 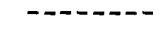 & $--n--$ & 5 & 5 & 1.796454 & .439200 \\
\hline 09216545 & - & - & - - - & ----- & 15 & 15 & 1.528279 & .280901 \\
\hline 09216562 & 4 & 4 & -----o- & --n-c- & 10 & 10 & 1.604372 & .270300 \\
\hline 09216565 & 3 & 6 & --n-- & 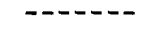 & 11 & 11 & 1.452835 & .427063 \\
\hline 09216576 & 2 & 4 & - - - & $-\cdots--$ & 5 & 5 & 1.336248 & .252922 \\
\hline 09216750 & 2 & 2 & - & --n--- & 12 & 12 & 2.407419 & - - - - \\
\hline 09216810 & 12 & 12 & 1.342717 & .216335 & 12 & 12 & 1.727641 & .144387 \\
\hline 09216880 & 12 & 12 & 1.215361 & .197282 & 12 & 12 & 1.672141 & .379441 \\
\hline 09217000 & 11 & 13 & .919952 & .382234 & 12 & 12 & 1.190275 & .253936 \\
\hline 09217010 & 10 & 13 & .954629 & .210667 & 12 & 12 & 1.115017 & .173497 \\
\hline 09222300 & 5 & 5 & 1.215836 & .243899 & 14 & 14 & 1.552561 & .238731 \\
\hline 09222400 & 4 & 5 & .947439 & .433372 & 16 & 16 & 1.491454 & .364050 \\
\hline 09224050 & 9 & 12 & ----- & ------ & 12 & 12 & 1.241008 & .394740 \\
\hline 09235300 & 4 & 5 & 1.093829 & .341455 & 13 & 13 & 1.683755 & .709803 \\
\hline 09257000 & 3 & 6 & --n-- & --n-- & 5 & 5 & .996866 & .308909 \\
\hline
\end{tabular}




\subsection{STATISTICAL SUMMARY OF TRACE-ELEMENT CONCENTRATIONS}

AT ROUTINE SURFACE-WATER SAMPLING STATIONS--Continued

8.0 STATISTICAL SUMMARY OF TRACE ELEMENTS--CONTINUED

\section{LITHIUM}

\begin{tabular}{|c|c|c|c|c|c|c|c|c|}
\hline \multirow{2}{*}{$\begin{array}{l}\text { Site or } \\
\text { Station }\end{array}$} & \multicolumn{4}{|c|}{ Dissolved } & \multicolumn{4}{|c|}{ Total } \\
\hline & $\mathrm{N} 1$ & $\mathrm{~N} 2$ & Log Mean & Log SD & N1 & $\mathrm{N} 2$ & Log Mean & Log SD \\
\hline Misc-SW & 8 & 8 & 1.632546 & 0.519093 & 7 & 7 & 1.765445 & 0.386219 \\
\hline Springs & 9 & 10 & 1.324586 & .399124 & 11 & 14 & 1.280540 & .360265 \\
\hline 09209400 & 8 & 12 & .786650 & .221763 & 12 & 13 & .962015 & .374549 \\
\hline 09211200 & 5 & 11 & .725219 & .252495 & 11 & 12 & .920644 & .216203 \\
\hline 09216000 & 12 & 12 & 1.543404 & .190029 & 12 & 12 & 1.572303 & .211556 \\
\hline 09216527 & 2 & 2 & $\ldots \ldots$ & 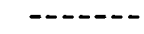 & 5 & 5 & 1.637278 & .159310 \\
\hline 09216545 & 4 & 4 & 1.798836 & .143467 & 15 & 15 & 1.798008 & .087710 \\
\hline 09216562 & 4 & 4 & 3.328993 & .179931 & 10 & 10 & 2.184411 & .207562 \\
\hline 09216565 & 4 & 4 & 2.019795 & ------ & 10 & 10 & 1.623754 & .179381 \\
\hline 09216576 & 3 & 3 & 1.700124 & ------ & 5 & 5 & 1.775704 & .148912 \\
\hline 09216750 & 2 & 2 & 2.303728 & $---\cdots$ & 8 & 8 & 2.347035 & .119905 \\
\hline 09216810 & 12 & 12 & 2.581393 & .209001 & 12 & 12 & 2.003110 & .287161 \\
\hline 09216880 & 12 & 12 & 2.001080 & .267131 & - & - & 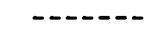 & 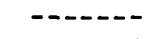 \\
\hline 09217000 & 12 & 12 & .944538 & .250176 & 13 & 13 & 1.080709 & .231994 \\
\hline 09217010 & 12 & 13 & 1.008945 & .163110 & 13 & 13 & 1.094254 & .185240 \\
\hline 09222300 & 5 & 5 & 1.890124 & .121724 & 14 & 14 & 1.975659 & .142084 \\
\hline 09222400 & 4 & 4 & 2.112620 & .352620 & 15 & 15 & 2.110786 & .296124 \\
\hline 09224050 & 12 & 12 & 1.006598 & .186333 & 12 & 12 & 1.088904 & .245827 \\
\hline 09235300 & 4 & 4 & 1.857357 & .070703 & 13 & 13 & 1.967343 & .230328 \\
\hline
\end{tabular}

SELENIUM

\begin{tabular}{|c|c|c|c|c|c|c|c|c|}
\hline \multirow{2}{*}{$\begin{array}{l}\text { Site or } \\
\text { Station }\end{array}$} & \multicolumn{4}{|c|}{ Dissolved } & \multicolumn{4}{|c|}{ Total } \\
\hline & $\mathrm{N} 1$ & $\mathrm{~N} 2$ & Log Mean & Log SD & $\overline{\mathrm{N} 1}$ & N2 & Log Mean & Log SD \\
\hline Misc-SW & 11 & 28 & -0.215167 & 0.330025 & 16 & 22 & 0.250972 & 0.589242 \\
\hline Springs & 6 & 18 & -.385419 & .690792 & 15 & 43 & -.334270 & .726928 \\
\hline 09209400 & - & - & 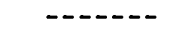 & $\ldots-$ & 1 & 13 & ---- & ---- \\
\hline 09211200 & - & - & $-\ldots-\ldots$ & ----- & 1 & 12 & ------ & ------- \\
\hline 09216000 & 12 & 12 & .296359 & .325257 & 13 & 13 & .367550 & .331818 \\
\hline 09216527 & - & - & $-\cdots--$ & $-\ldots-\cdots$ & 2 & 5 & $\ldots \ldots$ & $-\cdots-$. \\
\hline 09216545 & 2 & 4 & ----- & $-\ldots-\ldots$ & 10 & 15 & -.040697 & .137239 \\
\hline 09216562 & 4 & 4 & .475772 & .628479 & 10 & 10 & .527397 & .543573 \\
\hline 09216565 & 5 & 6 & ----1 & 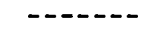 & 10 & 11 & 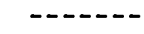 & $--\cdots$ \\
\hline 09216576 & 3 & 4 & $-\ldots-.-$ & ------ & 5 & 5 & .060206 & ----- \\
\hline 09216750 & 2 & 2 & .150515 & $\ldots-\ldots$ & 8 & 8 & .651189 & .242497 \\
\hline 09216810 & 10 & 12 & .031903 & .276520 & 11 & 12 & .088521 & .248603 \\
\hline 09216880 & 5 & 12 & 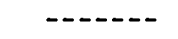 & $--\ldots-\infty$ & 7 & 12 & -.061425 & .343872 \\
\hline 09217000 & - & - & 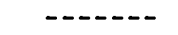 & $\ldots-$ & 3 & 13 & ---- & 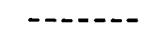 \\
\hline 09217010 & 1 & 13 & ------ & ------ & 4 & 13 & - & $-\ldots$ \\
\hline 09222300 & 4 & 5 & .555508 & .499714 & 14 & 14 & .667948 & .365931 \\
\hline 09222400 & 5 & 5 & .406685 & .318780 & 16 & 16 & .286248 & .358683 \\
\hline 09224050 & 1 & 12 & ------ & ------ & 1 & 12 & $---\cdots$ & ------ \\
\hline 09235300 & 3 & 5 & ------ & ----- & 10 & 13 & .000737 & .338809 \\
\hline
\end{tabular}



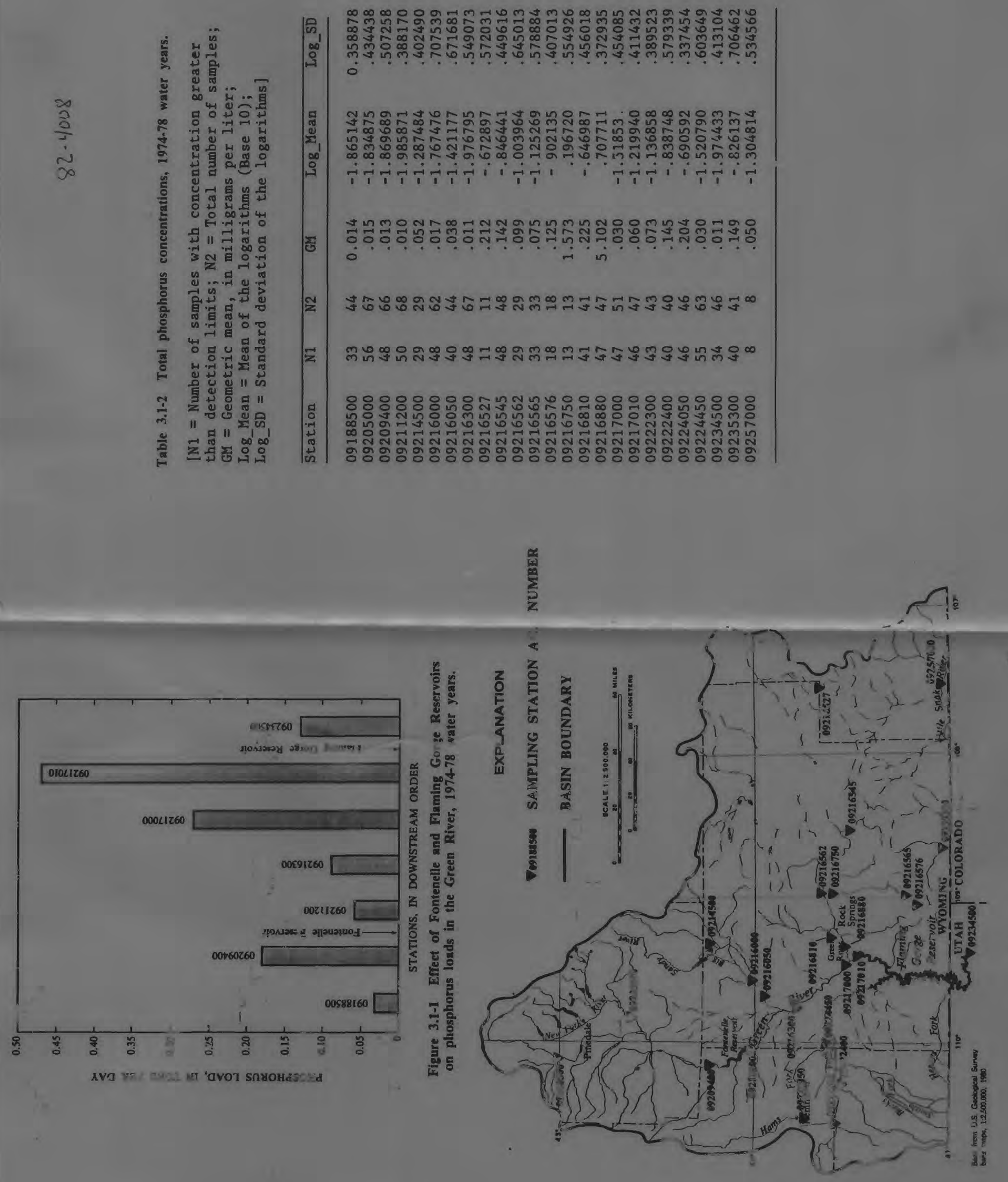